\title{
Evidence for surface uplift of the Atlas Mountains and the surrounding peripheral plateaux: Combining apatite fission-track results and geomorphic indicators in the Western Moroccan Meseta (coastal Variscan Paleozoic basement)
}

\author{
L. Barbero ${ }^{\mathrm{a}, *}$, A. Jabaloy ${ }^{\mathrm{b}}$, D. Gómez-Ortiz ${ }^{\mathrm{c}}$, J.V. Pérez-Peña ${ }^{\mathrm{b}}$, M.J. Rodríguez-Peces ${ }^{\mathrm{b}}$, R. Tejero ${ }^{\mathrm{d}}$, \\ J. Estupiñán ${ }^{a}$, A. Azdimousa ${ }^{e}, M$. Vázquez ${ }^{b}$, L. Asebriy ${ }^{\mathrm{f}}$ \\ a Dpto. Ciencias de la Tierra, Universidad de Cádiz, 11510 Puerto Real, Cádiz, Spain \\ ' Dpto. Geodinámica, Universidad de Granada, Spain \\ c ESCET-Área de Geología, Universidad Rey Juan Carlos, Móstoles, 28933 Madrid, Spain \\ d Dpto. Geodinámica, Universidad Complutense de Madrid, 28040 Madrid, Spain \\ e Faculté Pluridisplinaire Nador, Selouane, Universitè Mohammed I, Oujda, Morocco \\ ${ }^{\mathrm{f}}$ Institut Scientifique, Universitè Mohammed V, Agdal-Rabat, Morocco
}

\section{A R T I C L E I N F O}

\section{Article history:}

Received 3 March 2009

Received in revised form 4 December 2009

Accepted 9 January 2010

Available online $\mathrm{xxxx}$

\section{Keywords:}

Topography and 4D evolution

Low temperature thermochronology

Catchment hypsometry

Moroccan Atlasic-Variscan Meseta relationship

\begin{abstract}
A B S T R A C T
This work represents an initial attempt to link the evolution of the topography in relation to the general tectonic framework of western Morocco. For this purpose, in a section of the Western Moroccan Meseta different tools are combined in order to attain the general objective. Apatite fission-track (AFT) data of granitic rocks of the Rabat-Khenifra area give ages around 200 Ma with track length distributions which are compatible with the thermal models already established for the area. An inverse correlation between AFT ages and elevation is observed which is compatible with previous models indicating northward tilting of the whole Western Moroccan Meseta which is younger than 20-25 Ma. In order to test this possibility a detailed analysis of the topography at different scales in the Western Moroccan Meseta has been performed. Results indicate that two open folds with different amplitudes are recognized and that the one with wider wavelength could correspond to a lithospheric fold as previously stated by other authors on the basis of independent geological arguments. The northward tilting proposed based on the AFT data agrees with the results obtained in the analysis of the topography which reinforces the presence of a very open fold with a wavelength of 200-300 km in the north-western limb of the Western Moroccan Meseta.
\end{abstract}

(c) 2010 Published by Elsevier B.V.

\section{Introduction}

The northern part of Morocco comprises the Atlas mountains and several mesetas with a flat morphology. All of them constitute the foreland of the Alpine Rif-Tell orogen, located at the southern margin of the Western Mediterranean (Fig. 1).

The Atlas is a linear mountain belt trending SW-NE which in its central part is divided into two branches: the so-called Middle Atlas which follows a SSW-NNE direction and the High Atlas trending approximately E-W. The Atlas can be considered as a typical intracontinental orogen (Laville, 1985) related to the far-field effects of the NW-SE movement of the European plate with respect to the African plate (Teixell et al., 2008). For these authors, the evolution and chronology of the Atlas is relatively independent of the evolution of the Rif-Tell orogen. The so-called Anti-Atlas, located southwards of the Atlas, represents an extensive massif with a characteristic

\footnotetext{
* Corresponding author. Tel.: + 34956 016279; fax: + 34956016019 E-mail address: luis.barbero@uca.es (L. Barbero).
}

topography not characterized by high elevations in comparison to the High Atlas and related to scarce Alpine activity.

The Western Moroccan Meseta has a central part with reliefs higher than $1600 \mathrm{~m}$. Fullea-Urchulutegui et al. (2006) performed a model of the crustal and lithospheric thicknesses in Morocco that indicates a relatively thin crust below the Moroccan Meseta (around 26-28 km) and a crustal thickening increasing up to $38 \mathrm{~km}$ below the highest parts of the High Atlas. Recent studies demonstrate that the High Atlas crustal root is not thick enough to isostatically explain the high topography of this mountain range (Teixell et al., 2003; Teixell et al., 2005; Zeyen et al. 2005; Ayarza et al., 2005; Missenard et al., 2006; Fullea et al., 2007). These studies propose that a NE-SW trending uplift of the asthenosphere below the Western High Atlas, central Anti-Atlas and Middle Atlas exists, and that thermal doming accounts for the elevation of the area, in addition to the moderate shortening and crustal thickening (Zeyen et al., 2005; Teixell et al., 2005; Ayarza et al., 2005; Missenard et al., 2006; Fullea et al., 2007). Also, this model explains the presence of alkaline magmatism coeval with the main compression event, and the scarce sedimentary record found in the small foreland basins to the north and south of the Atlasic system. 
A

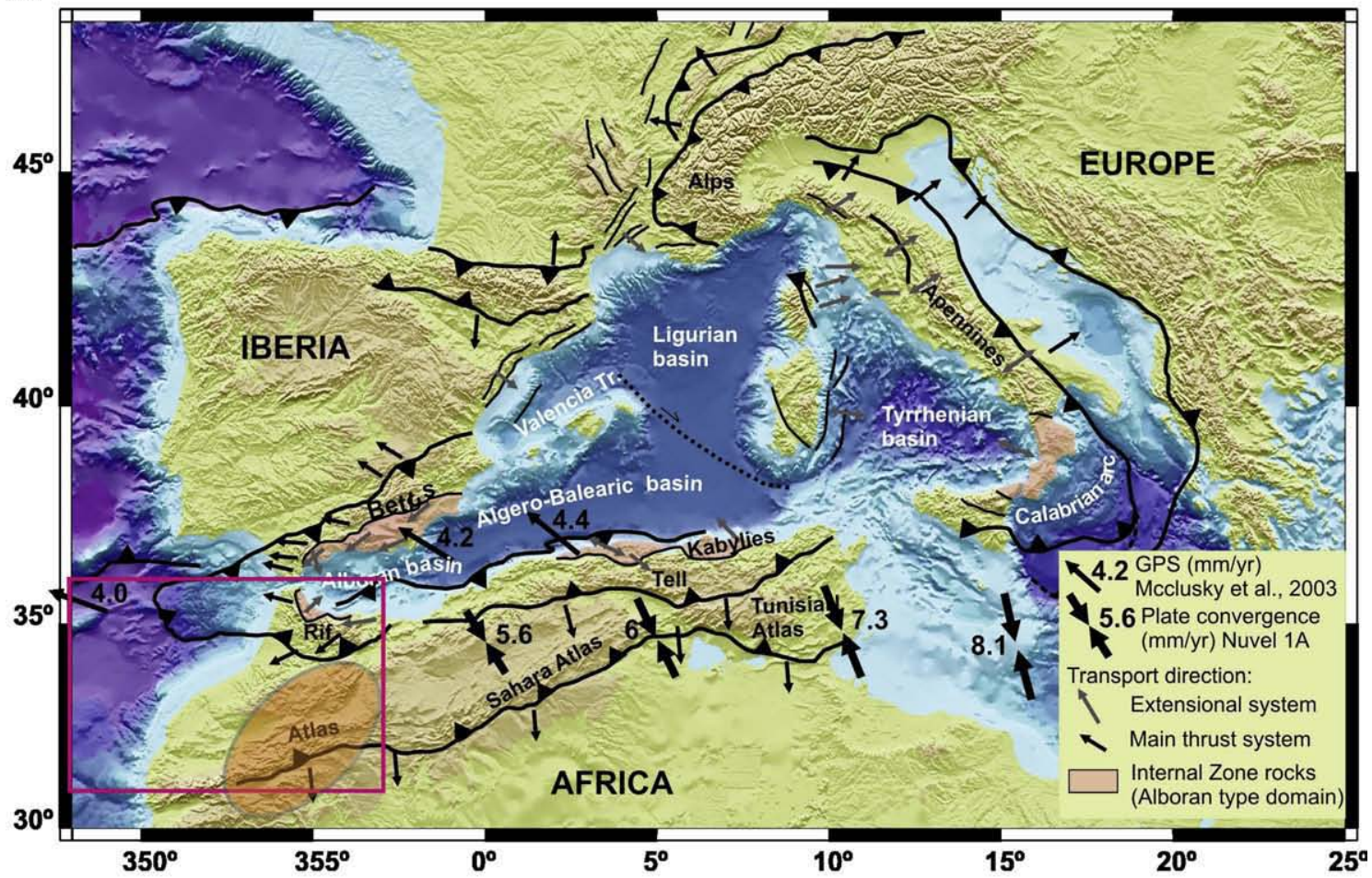

B

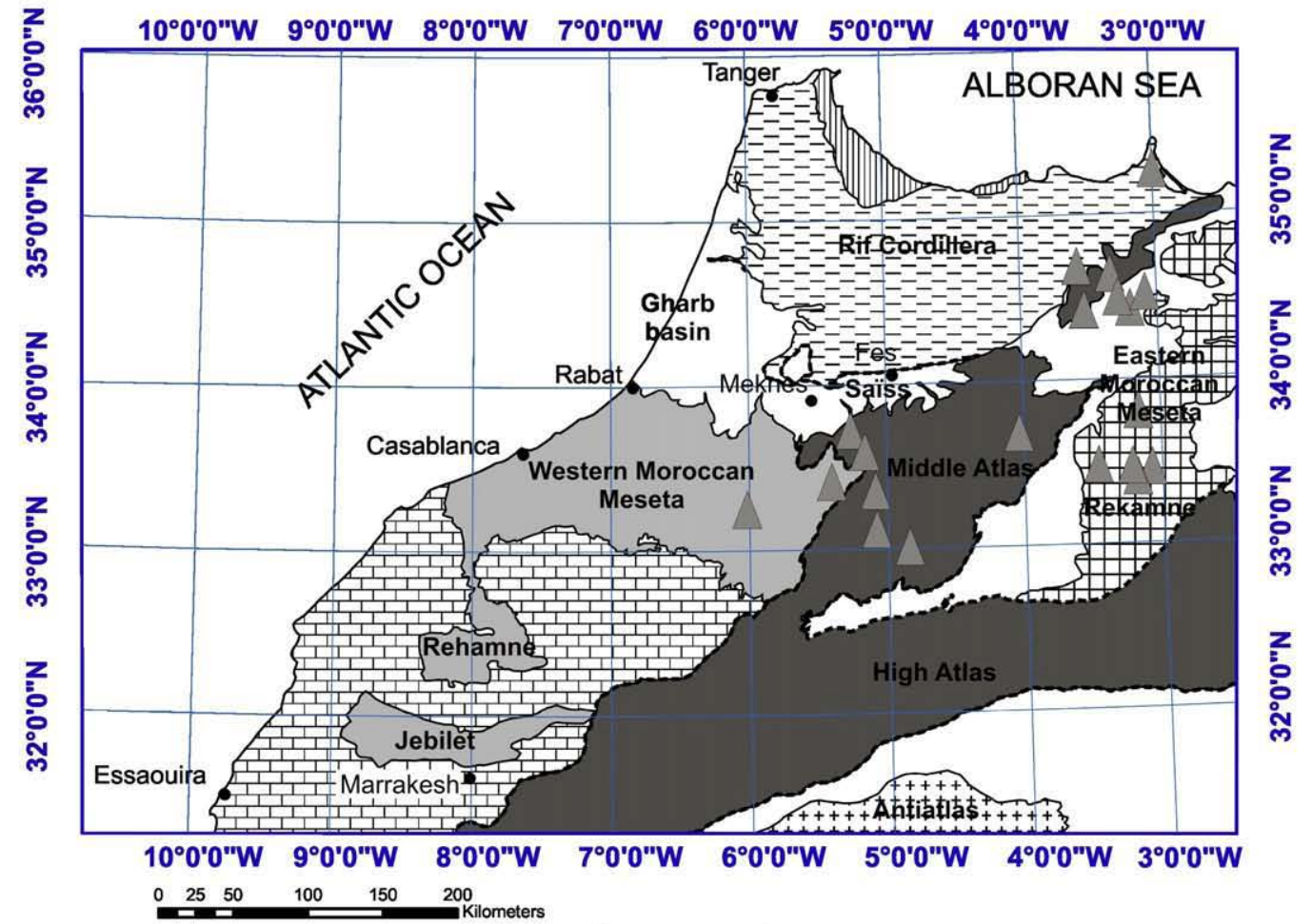

Legend

Neogene to present-day sedimentary basins

External Rif

and Flyschs

Internal Rif
Mesozoic cover deformed in the Alpine Orogeny

Metamorfic basement
deformed in the Variscan Orogent

Mesozoic cover undeformed

in the Alpine Orogeny
Paleozoic Variscan Basement

(Eastern Meseta) and undeformed Mesozoic cover (Rekamne)

deformed in the Pan

Deformational front

Pliocene to Quaternary Volcano 
Recently, Babault et al. (2008) have demonstrated that the Atlas Mountains have been uplifted by two mechanisms: Cenozoic thickening of the crust and thinning of the mantle lithosphere due to a buoyant thermal anomaly. This rising of the asthenosphere has been inferred, by indirect criteria, to have started around $15 \mathrm{Ma}$. The indirect geological evidences are the presence of elevated marine sediments, tilted paleohorizontal markers, and drainage-network reorganization in the southern margin of the Saïss Basin and the northern middle Atlas regions (Figs. 1 and 2). Moreover, in a recent paper Ghorbal et al. (2008) documented unexpected stages of subsidence and exhumation affecting the whole Moroccan Meseta from the Jurassic to Tertiary and this is challenging the traditional stability of NW Africa (Michard, 1976; Michard et al., 1989; Guiraud et al., 2005).

In this context, the relief of the Western Moroccan Meseta and its evolution has not been studied in depth. The main aim of this work is to analyze of Neogene-Quaternary landscape evolution, and we present here two different approaches that indicate that this relief is recent and active. We present here new apatite fission-track data from apatites recovered in granitoids from the Western Moroccan Meseta in a cross section from Rabat to Khenifra (Fig. 2). Moreover, the present-day topography is studied by the combination of a trendtopographic surface analysis (large scale) and a hypsometric analysis of its drainage network (medium scale). All these data combined help to determine the recent evolution of the Western Moroccan Meseta and to assess the presence of active folding within the area.

\section{Geological setting, topography and geomorphic indicators}

Between the Rifean orogen and the Atlas chain, several massifs of metamorphic and granitic rocks of Palaeozoic age are found. They constitute the massifs of Rehamna, Jebilet and the Western and Eastern Moroccan Mesetas (Figs. 1 and 2). Ait Brahim et al. (2002) made a study on the tectonic evolution of the North African margin from late Paleozoic to present based on paleo-stress data. They conclude that the evolution of north Morocco is characterized by a NW-SE to NE-SW extensional period from late Triassic until Early Cretaceous related to the opening of the Atlasic and Atlantic rift systems. From the Late Cretaceous to Late Paleocene, a compressional regime with E-W to WNW-ESE directions evidenced by the presence of strike-slip faults in the northwestern part of the Atlas Mountains is recognized. This compressional event continued during the Eocene but following an $\mathrm{N}-\mathrm{S}$ direction as evidenced by the presence of inverse faults and folds in the Atlasic areas. From the Oligocene to Middle Miocene, the compression continued but changing to NE-SW trends in relation with the continuous collision between the African and European plates.

The Moroccan Meseta is composed by two main outcrops of Paleozoic rocks deformed during the Variscan orogeny; the Western and the Eastern Meseta, separated by the Middle Atlas Alpine chain. The Western Meseta (WM) presents a general low relief that increases eastwards from the seal level up to $1600 \mathrm{~m}$ of altitude in its central part.

The southern limit of the WM corresponds to the northern flank of a very open synform formed by Middle Cretaceous to Paleogene deposits that unconformably cover Paleozoic rocks. The southern limb of this synform includes detritic red facies from the Late Jurassic to Early Cretaceous. Southwards from this synform the Paleozoic rocks crop out again in the so-called Rehamna region. The western limit of the WM is a group of Paleozoic outcrops known as the Coastal Block that is covered by thin Quaternary deposits of coastal terraces and dunes. Towards the north, the WM lose elevation and the Paleozoic rocks are unconformably covered by the Neogene to Holocene deposits of the Gharb plain. This plain, together with the Saiis plain, constitutes the foreland basin of the Rif system and it is deformed in the area of the Volubilis basin by very recent thrusts as a continuation of the Rif deformational front (Bargach et al., 2004).

The Paleozoic rocks of the WM, Rehamna region, and Coastal Block include mainly siliciclastic rock (shales and quartzites) with small intercalations of sedimentary carbonatic rocks and basalts. This sequence presents ages ranging from Early Cambrian to Early Permian, and it was deformed essentially during the WestphalianStephanian times (320 to $290 \mathrm{Ma}$, El Hadi et al., 2006, and references therein). Late Carboniferous to Early Permian rhyolites filling dykes or as lava levels outcrop near the Middle Atlas deformational front, in the surroundings of the locality of Khenifra. The top of this Paleozoic sequence is formed by detritic rocks with red beds facies of Permian ages present in some outcrops within the WM.

The Coastal block is characterized by weak Variscan deformation and is limited eastwards by a narrow fault zone that dips towards the east and that is known as the West Meseta Shear Zone (WMSZ in Figs. 2 and 9B) (i.e. Hoepffner et al. 2005; Michard et al., 2008). In the central part of the WM, outcrops the hanging wall of the West Meseta Shear Zone called the Central Meseta Block. This Central Meseta Block is characterized by strong Variscan shortening accommodated by thrusts, SE-vergent folds and internal deformation. The thrusts dip towards the southeast and the most important ones are the SmaalaOulmez Fault Zone (SOFZ in Figs. 2 and 9) and the Tizi n'Tretten Fault (TTF in Figs. 2 and 9B) (i.e. Hoepffner et al. 2005; Michard et al., 2008). This later thrust has as hanging wall the Nappe Zone, formed by several thrust units. Towards the east, the Nappe Zone is separated from the Eastern Meseta by an NNE-SSW striking fault zone that dips towards the SSE called the Tazekka-Bsabis-Bekrit fault zone (TBBFZ in Figs. 2 and 9B) (i.e. Hoepffner et al. 2005; Michard et al., 2008). The Eastern Meseta is characterized by lower and middle Paleozoic deformed by eovariscan events and small carboniferous basins with calcalkaline volcanism (i.e. Hoepffner et al. 2005; Michard et al., 2008).

Near Rabat, outcrops the Sehoul Block that is an allochthonous terrane deformed during the Caledonian orogeny (i.e. Hoepffner et al. 2005; Michard et al., 2008). This allochthonous terrane thrust over the Central Meseta Block and below the main thrust surface outcrops a thin unit in the Tiflet area composed by the Proterozoic basement of the Central Meseta block (Tahiri et al., 2009).

There are several granite bodies that intrude this Paleozoic sequence. In the WM can be recognized three larges bodies that correspond to the batholites of Zaër, Oulmès, and Ment (Fig. 2). These granite bodies are biotite granodiorites to two micas monzogranites (Mahmood and Bennani, 1983). In the Rehamna region there is also the Rehamna Batholit formed by monzogranites and leucogranites. The ages for the WM granites obtained by $\mathrm{Rb}-\mathrm{Sr}$ range between 330 to $260 \mathrm{Ma}$, however, U-Pb ages in zircons and monazites indicate ages between the $315 \pm 9$ Ma to $291 \pm 16$ Ma for the Zaër granite (Chèvromont et al., 2001 ), and between $308 \pm 8 \mathrm{Ma}$ to $296.2 \pm 2.9 \mathrm{Ma}$ for the Oulmès granitic body (Baudin et al., 2001), while the Ment granite lacks U-Pb ages for the moment.

Apart of these three large bodies, there are also several small bodies with generally less than $1 \mathrm{~km}^{2}$ in the Tiflet area and the Sehoul Block. The studied samples (samples BJE and TA) are only from the two Tiflet granitoid bodies (namely Taïcha: TA, and Bou Jemaa, BJE, Tahiri et al., 2009), as those of the Sehoul block are much fractured and their apatites were not suitable for fission tracks. The zircons of these samples have been recently dated by Laser Ablation-ICPMS

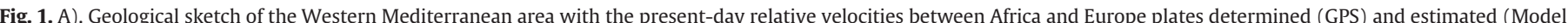

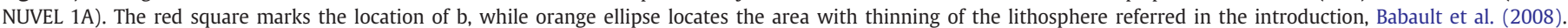

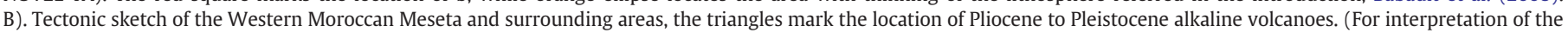
references to colour in this figure legend, the reader is referred to the web version of this article.) 


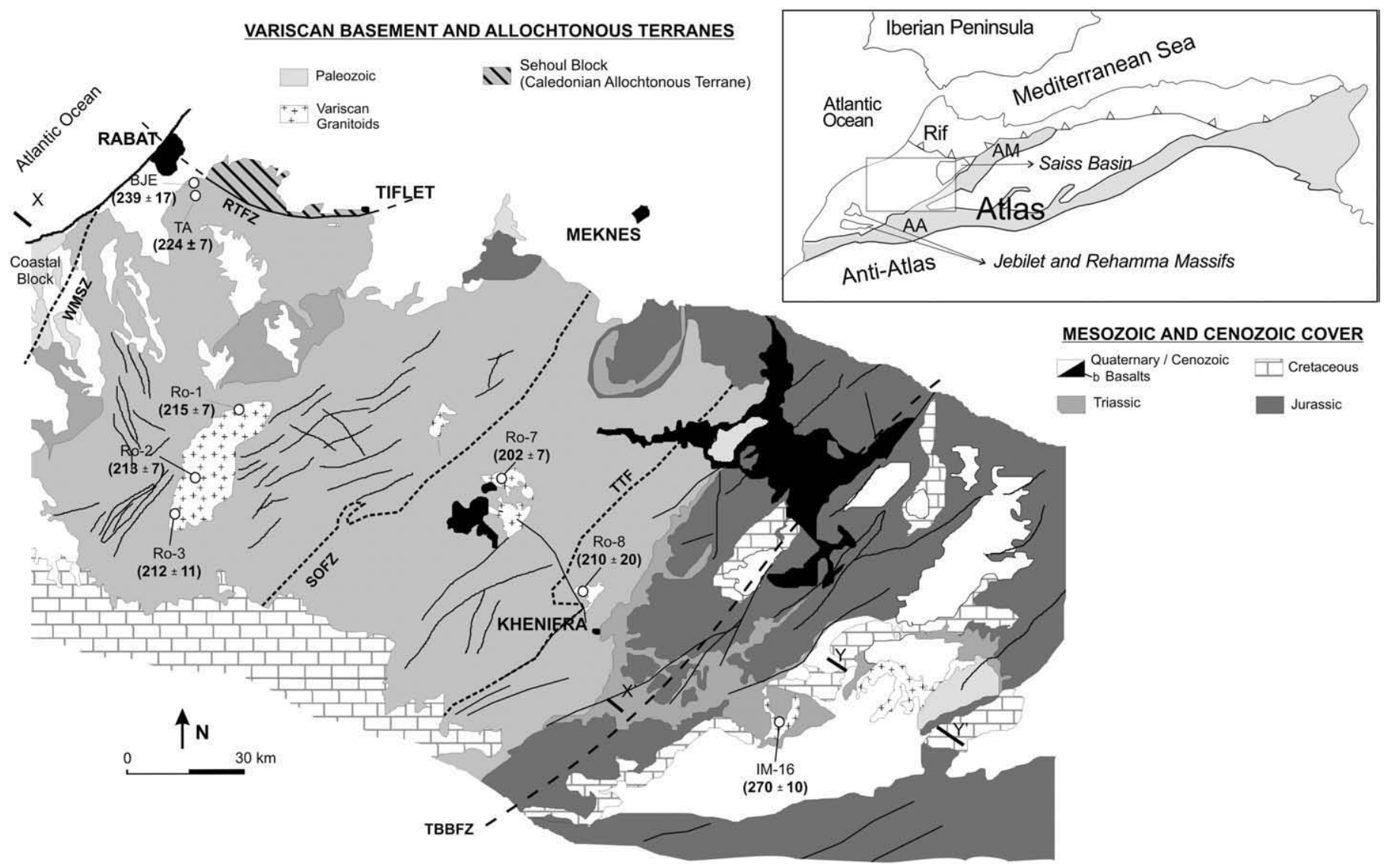

Fig. 2. Geological map of the Western Moroccan Meseta with the location of the samples and their AFT ages.

analyses (Tahiri et al., 2009) and yield a mean U-Pb age of $606 \pm 6 \mathrm{Ma}$ for the sample TA from Taïcha body, and a mean U-Pb age of $605 \pm$ $4 \mathrm{Ma}$ for the sample BJE of the present study near Rabat. Both granitoids as other from the Tiflet area are Proterozoic granitoids with many features typical of Andean-arc granitoids, with an important crustal component (Tahiri et al., 2009).

Scarce previous thermochronological data on the region have been provided by Ghorbal et al. (2008). They provide one AFT data on the Zäer granitic body with an age of $148 \pm 6$ Ma with a mean track length of $13.48 \pm 0.2 \mu \mathrm{m}$. Additionally, three corrected (U-Th)/He ages on the same pluton ranges from 51 to $243 \mathrm{Ma}$. Replicates within individual samples are in agreement only in one sample (sample number $1: 160.9 \pm 11.7,166.8 \pm 11.7$ and $171.0 \pm 11.5 \mathrm{Ma})$ meanwhile in the other two samples individual (U-Th)/He ages do not replicate (sample 2: $181.8 \pm 13.7,51.8 \pm 10.5$ and $50.6 \pm 7.0 \mathrm{Ma}$; and sample 3: $242.9 \pm 17.5,178.5 \pm 12.9$ and $205.3 \pm 14.9 \mathrm{Ma}$ ). Whether this dispersion in He ages is related to the thermal evolution of the area or to experimental problems has not been discussed by the former authors.

The relief of the area is characterized to the west by the coastal terraces, where Quaternary deposits cover the Paleozoic rocks of the Coastal block. These deposits and the Paleozoic rocks are incised by the channels of the rivers that drain the WM (Fig. 3). The main water channels have NW-SE trends and from the northeast to the southwest they are the channels of the Oued Bou Regreg, the Oued Cherrat, the Oued Dir, and the Oued Mellah. Towards the south, is the river Oued Oum Er Rbia. The main channel of this latter river starts with NE-SW trends draining the deformational front of the Middle Atlas and the higher parts of the WM. In the middle part, the channel of the Oued Oum Er Erbia turns to an E-W trend, and latter, in its final part, the water channel has a main NW-SE trend, parallel to the other mentioned rivers.
Between the Oued Mellah and the Oued Oum Er Rbia, near Casablanca, the drainage net is filled by the dunes and is not well developed. There is a main channel, the Oued Tamadrost that has its mouth in an endorrheic area of Sebkhas at around $200 \mathrm{~m}$ high between the coastal terraces and the dunes of the Coastal block.

The foreland basin defined by the Gharb and Saïs plains has an axial drainage along the channel of the Oued Sebou, and the northern part of the WM has several drainage catchments that belong to this river system. The principal ones are from west to the east the Oued Beht, the Oued Rdom and the Oued Mikkes, that join near the Oued Sebou main channel, and the Oued Srhina that pass near Fes.

\section{Topography and drainage analysis}

Topography analysis has been used to decipher the regional relief features in the Atlas Mountains and the WM. Two main analyses have been carried out at different scales; a trend-topographic surface analysis at large to medium scale, and a hypsometric analysis of the WM's drainage network at medium scale. Trend-topographic analysis provides useful data about the role of doming processes and folding and faulting structures in the construction of the relief. The hypsometric analysis focuses in the drainage network of the WM trying to evaluate medium-scale structures, as folds and thrusts that affect the relief in that area.

A Digital Elevation Model (DEM) with $90 \mathrm{~m}$ of pixel resolution provided by the Shuttle Radar Topography Mission (SRMT) from the National Geospatial-Intelligence Agency (NGA) and the National Aeronautics and Space Administration (NASA) has been used to perform the topographic analysis. This DEM can be acceded by anonymous ftp logging in ftp://e0srp01u.ecs.nasa.gov (Fig. 4). This DEM has been completed with the data below the sea level from GEBCO One Minute Grid (British Oceanographic Data Centre, 2003). 
A

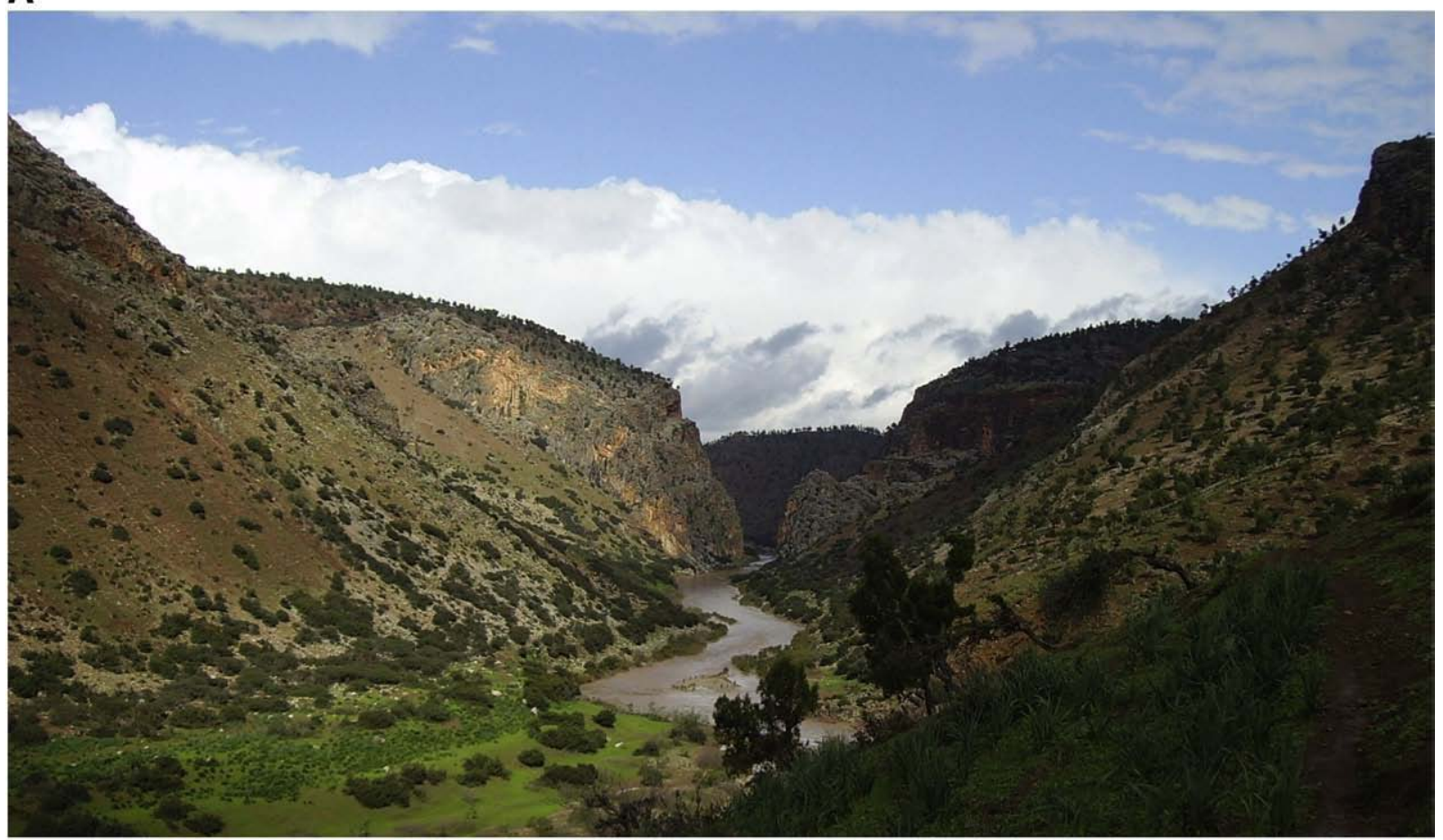

B

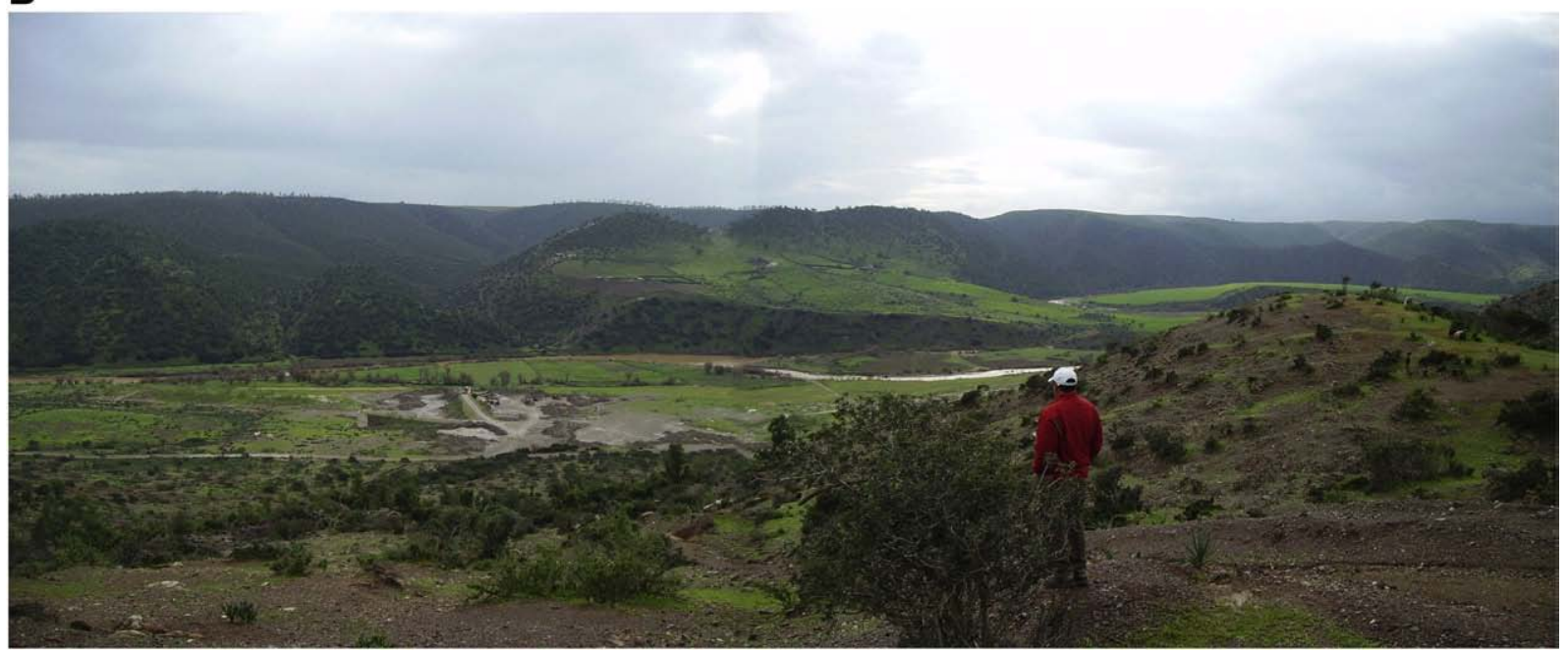

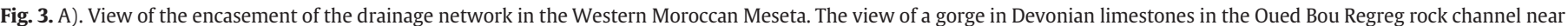

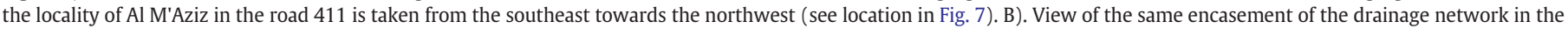

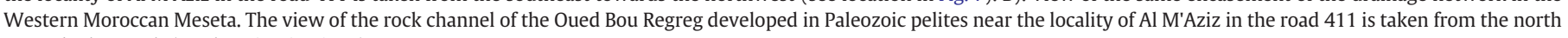
towards the south (see location in Fig. 8).

\subsection{Trend-topographic surface analysis}

To assess topographic features related to the main tectonic structures of the Atlas Mountains and the WM we performed a spectral analysis to yield trend-topography surfaces. These trendsurfaces are harmonic surfaces retrieved from the elevation data of the DEM by applying a Fourier analysis. This Fourier analysis provides quantitative information about the amplitude, orientation, and shape of these periodic or quasiperiodic harmonic surfaces for a determined wavelength. From a regional standpoint, main topographic features can be described by these harmonic surfaces (e.g. Rayner, 1972; Johansson, 1999; Sánchez-Serrano, 2000; Tejero et al., 2006).

We used the OASIS 6.4.2 software package to perform the spectral analysis over the DEM. We compared the obtained harmonic surfaces with the topography of the studied area in order to find those that better describe the main topographic feature at a regional scale and those that more accurately represent valleys and local water divides. We chose the harmonic surfaces of wavelength of 200, 100 and $60 \mathrm{~km}$. The surface corresponding with a $200 \mathrm{~km}$ wavelength is characterized by an NE-SW high defining the Atlas Range elevations (including both, the Middle and the High Atlas). This long-wave undulation can be related to the doming processes uplifting the Atlas Mountains as it images the depth of the lithosphere-asthenosphere boundary (FulleaUrchulutegui et al., 2006). Whereas the WM topography is undistinguishable in this larger wavelength, the harmonic surfaces obtained with 100 and $60 \mathrm{~km}$ wavelengths are but explanatory of its relief. Both harmonic surfaces show NE-SW lower-scale undulations (Fig. 5B, C). The undulations defining topographic highs represent the mountain alignments of the WM and the Atlas Mountains (continuous lines in Fig. $5 \mathrm{~B}$ ). The undulation that defines the main relative low (dashed line 


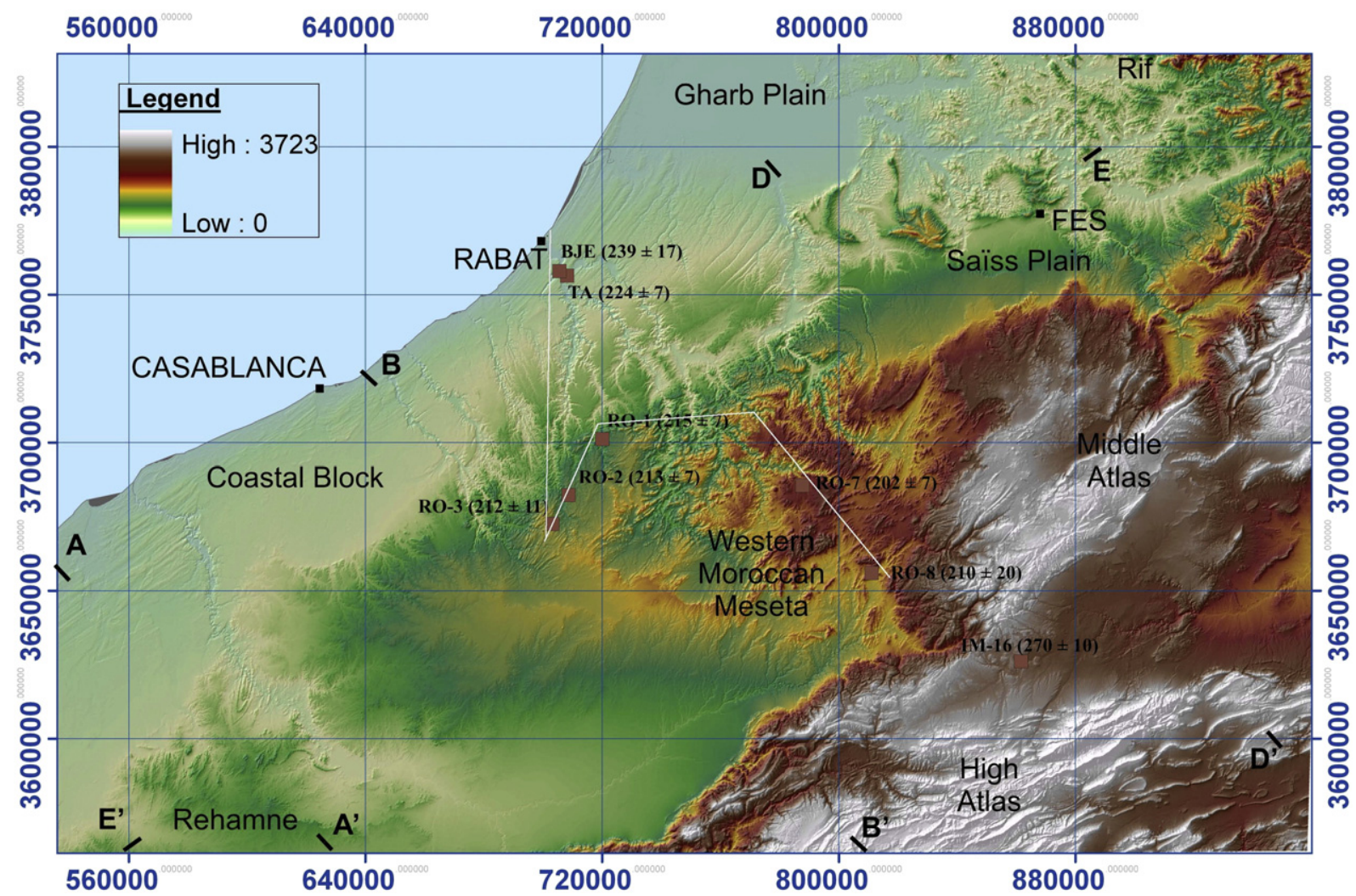

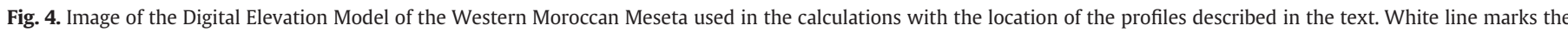
position of the profile in Fig. 9.

in Fig. 5B) corresponds with the NE-SW Oued Oum Er Rbia rivervalley (Fig. 7). This river flows northwestwards in this head part and then turns NW-SE to the coast running transverse to the WM mountain alignments (Fig. 7). In the harmonic surface of $60 \mathrm{~km}$ are visible other NW-SE undulations representing different river valleys of the WM (Fig. 5C).

In order to better define the amplitude and relations of the main undulations, we have drawn topographic profiles with their corresponding profiles for the 100 and $60 \mathrm{~km}$ harmonic surfaces. Four topographic profiles are transverse to the NE-SW main undulations (profiles A, B, C, and D in Fig. 6), and one parallel (profile $\mathrm{E}$ in Fig. 6). The profiles transverse to the NE-SW undulations illustrate the relations between the harmonic surfaces, the topography, and the tectonic structures. In all the transverse profiles it is visible a northwest tilt, probably related with the doming of the Atlas Mountains. In the WM the amplitude of the undulations is about $500 \mathrm{~m}$ and up to $1000 \mathrm{~m}$ is the High Atlas elevation is taking into account (profiles B and C in Fig. 6). Thrust structures are principally located at the bottom of flanks-undulations (Fig. 6).

\subsection{Hypsometric curves of the catchments}

In order to characterize the present-day topography of the WM at lower-to-medium scale and to relate it with medium-scale structures, we have performed a hypsometric analysis. The hypsometry is very sensitive to changes in the relief induced by climate and/or tectonics (Lifton and Chase, 1992; Ohmori, 1993; Masek et al., 1994; Pérez-Peña et al., 2009a,b).

The hypsometric curve for a catchment represents the relative proportion of the watershed area below a given altitude (Strahler, 1952; Schumm, 1956). Its shape is related with the stage of geomorphic development of the basin. Convex-shaped hypsometric curves are typical of a youthful stage; s-shaped curves are related to a maturity stage, and concave curves are indicative of a peneplain stage
(Strahler, 1952). In order to determine if the relief of the WM was a young or an old feature we have performed a hypsometric study of the main catchments. The hypsometric curve for a catchment represents the relative proportion of the watershed area below a given altitude (Strahler, 1952; Schumm, 1956). The shape of the hypsomethic curve is related to the geomorphic maturity of catchment. In this way, convex-shaped hypsometric curves are typical of youthful stages, sshaped curves are related to mature stages meanwhile concave curves indicate a final peneplain stage (Strahler, 1952). In the first stages of uplift, rivers tend to adjust their profiles by vertical down-cutting and most basin area is located in higher elevations (V-shaped valleys). As erosion continues, lateral erosion becomes more important, and, in the final stages of geomorphic development is the most important factor distributing basin area in lower altitudes (U-shaped valleys and peneplain stage). One advantage of the use of the hypsometric curves is that it not relies on having a detailed DEM, since this kind of analysis is robust against variations in DEM resolution (Hurtrez et al., 1999; Pérez-Peña et al., 2009a).

In order to carry out the hypsometric analysis, the drainage network and the main watersheds were extracted from the $90 \mathrm{~m}$ DEM by using GIS software. To ensure data consistency, the DEM was first pit-filled, i.e., the small imperfections in the elevation data as sinkholes and peaks were filled and removed respectively (Tarboton et al., 1991). The drainage network was extracted using the D8 (eight directions) method (O'Callaghan and Mark, 1984) over the pit-filled DEM.

This automatically-extracted river network was compared with topographic maps of Morocco in order to detect possible anomalous drainage flows, i.e. automatically-generated river reaches that do not correspond with a real flow in the topographic map or the aerial photograph. The main anomalous river channels are located northeast and southwestwards of the mouth of the Oued Oum Er Rbia river (Fig. 7). In this area the catchments of El-Jadida and Casablanca are not real (Fig. 7). The real rivers disappear into coastal dunes that 


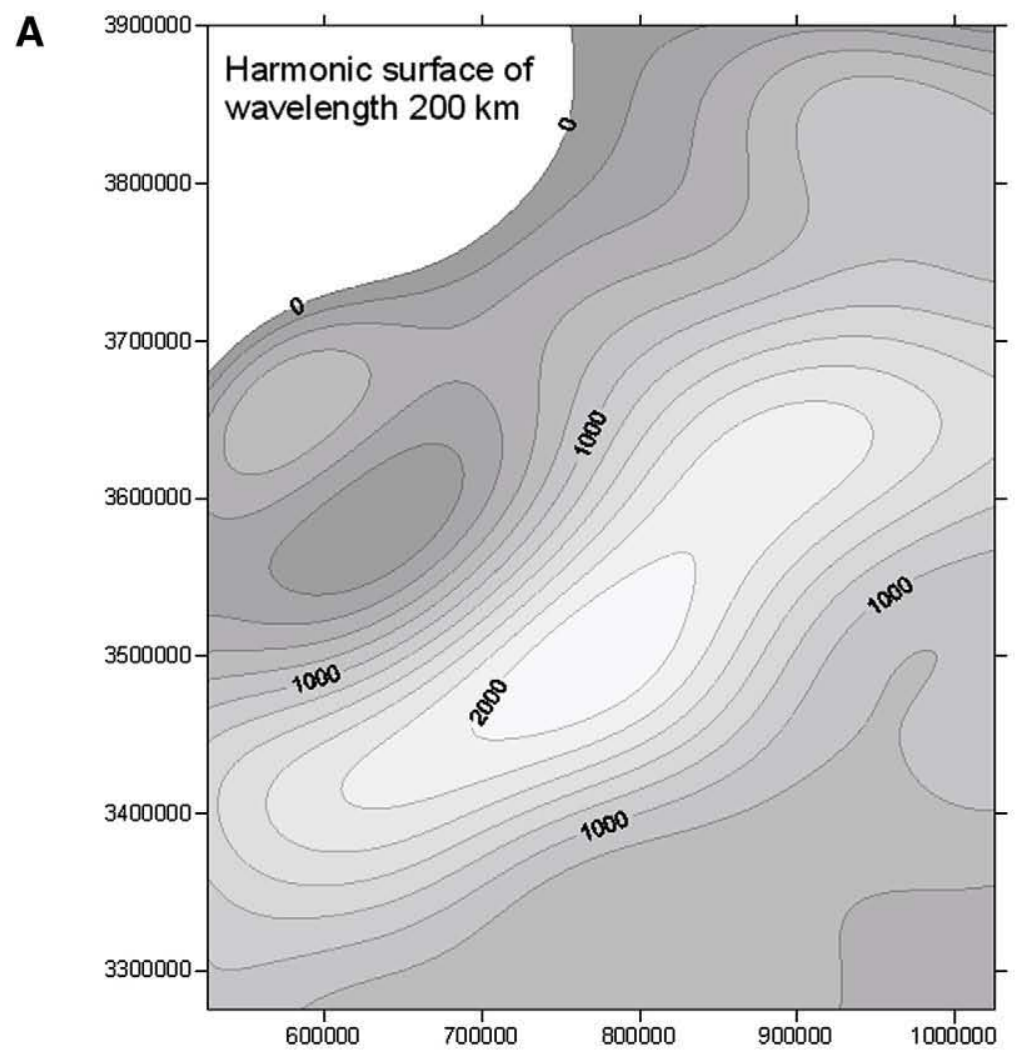

B
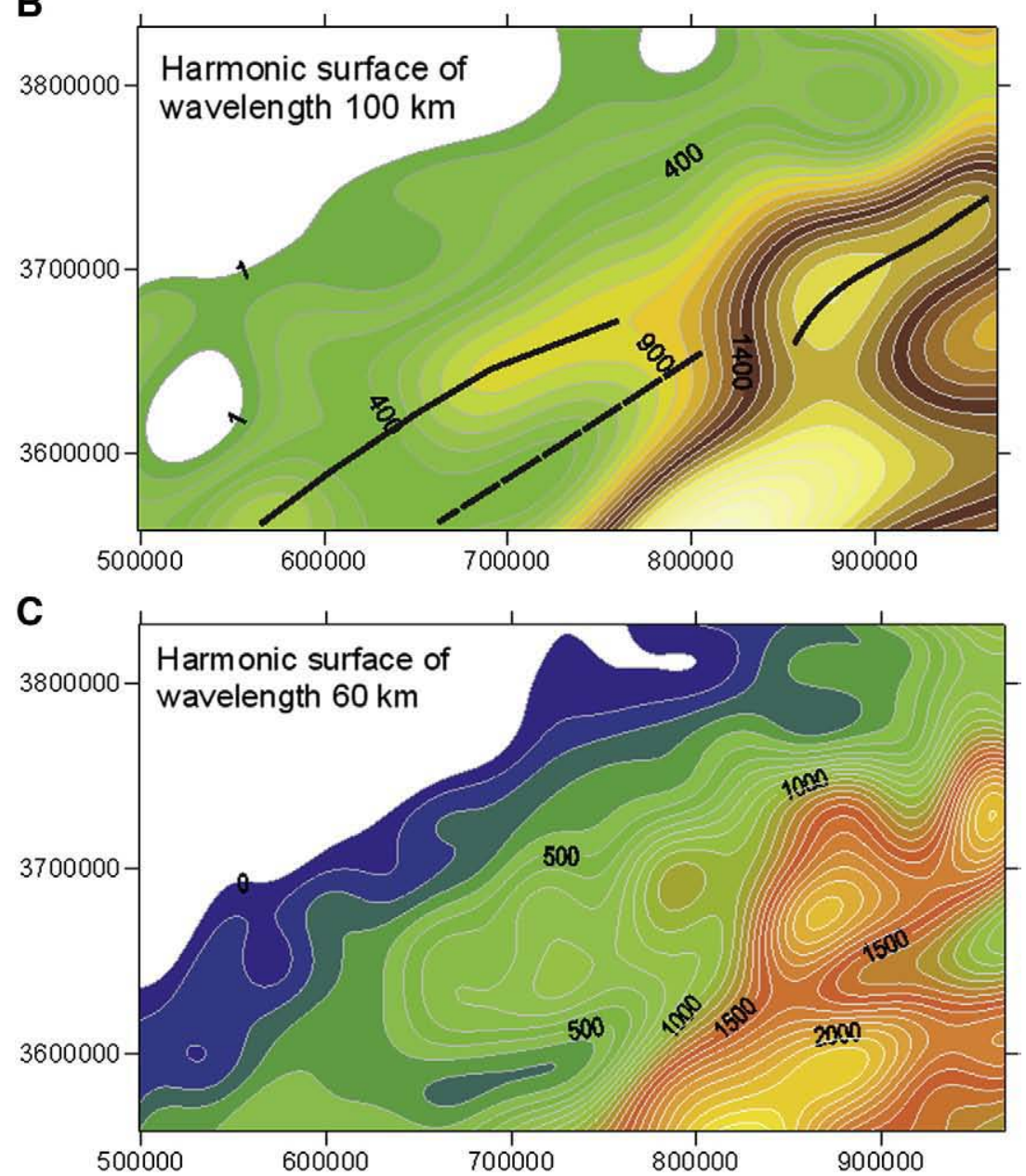

Fig. 5. Contour maps of harmonic surfaces of 200, 100 and $60 \mathrm{~km}$ estimated from the topographic data of the Digital Elevation Model. 


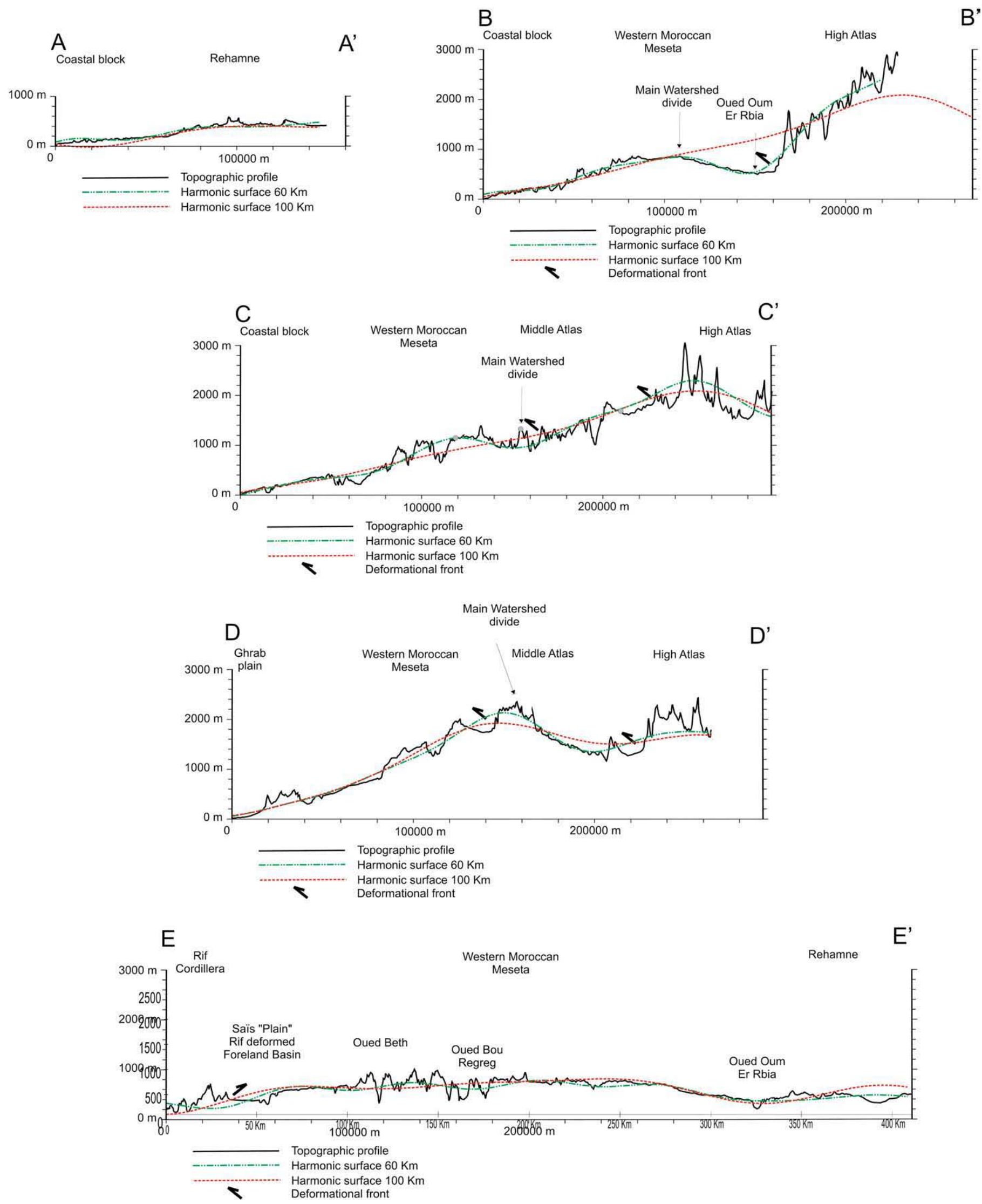

Fig. 6. Topographic profiles and corresponding 100 and $60 \mathrm{~km}$ undulations cross sections of the Western Moroccan Meseta. See Fig. 4 for location. 
L. Barbero et al. / Tectonophysics $x x x(2010) x x x-x x x$

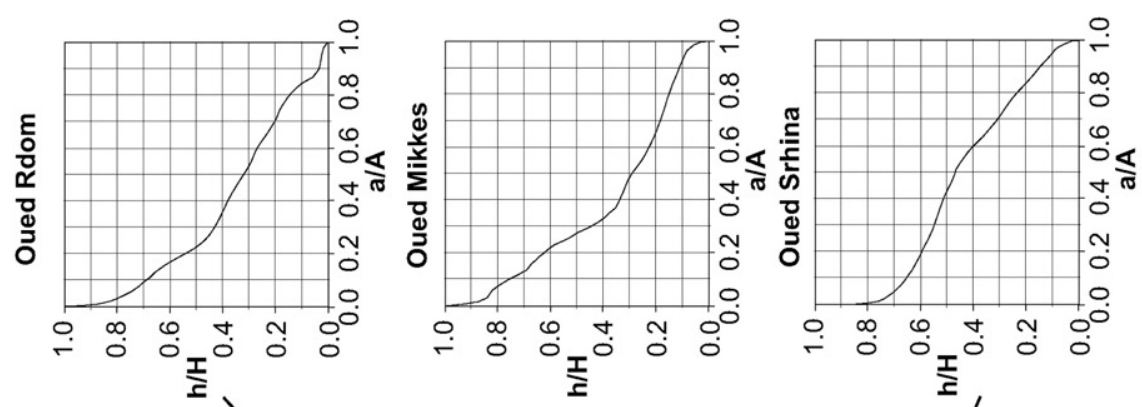


interrupt their flows. The filling of the sinkholes forces the flows through these dunes thus creating unreal channels. For this reason we considered these two catchments as artificial pseudo-catchments and their hypsometric curves were not calculated. The rest of the water channels coincide with the rock channels excavated in the Paleozoic rocks of the WM.

From the drainage network of the WM, we selected 11 main catchments by defining pour points in river mouths and using the aforementioned D8 method. From these catchments, we calculate the hypsometric curves for 9 watersheds (Fig. 7) with the aid of CalHypso GIS extension (Pérez-Peña et al., 2009a). The pseudo-catchments of El-Jaida and Casablanca were discarded by the reasons explained before. All the selected rivers flow roughly with an NW-SE direction except the Oued Oum Er Rbia (Fig. 7), which flows in its head-middle part with a NE-SW as mentioned earlier (Fig. 7). The large basins draining the core of the WM present a very interesting feature; the presence of a convex inflexion in their middle (Oued Mellat, Oued Bou Regreg, and Oued Beth) or head (Oued Rdam and Oued Mikkes) parts. These anomalies match with an undulation present in the trendtopographic analysis of the harmonic surfaces of 60 and $100 \mathrm{~km}$ wavelengths (Fig. 5B, C). Fig. 8 shows a Digital Elevation Model of the catchment of the Oued Bour Regreg to illustrate these anomalies. While the highest elevation within the watershed divide is $1551 \mathrm{~m}$ high, there are areas within the catchment that have higher altitudes, suggesting that the uplift of the area was very young and the river network incised the rising topography.

The presence of a convex inflexion in the hypsometric curve can be considered as an anomaly and it moves away of a normal basin development in the geomorphic cycle. Such anomalies indicate that the relief in that part of the basin is younger, and that the rivers are incising and creating V-shaped valleys. Moreover, as the rivers tend to attain a dynamic equilibrium in a relatively short time (in terms of geologic time), these anomalies in the drainage network should be related to relatively recent events.

\section{Apatite fission-track results, modelling and interpretation}

The apatite fission-track study has been carried out in samples from the Zaër, Oulmès and Ment granites and also from small granitic bodies near Rabat-Salé. We have also sampled rhyolite dykes near Khenifra. In Table 1 the result of fission-track analysis and methodology used are presented. The transect from Rabat-Salé to Khenifra spans along ca. $170 \mathrm{~km}$ and traverses the main Variscan structure. The northern limit to the west is the Rabat-Tiflet fault Zone, and toward the southeast is bounded by the so-called Tazekka-Bsabis-Bekrit Fault Zone. Along the transect, two subzones could be distinguished, which are separated by the Smaala-Oulmès fault zone (Fig. 2). For the purpose of this work and in order to interpret and age vs. elevation relationship, it is important to know whether the Variscan structures have been reactivated during subsequent deformation events. The paleo-stress directions estimated by Ait Brahim et al. (2002) in relation to previous Variscan structures indicate that, with the exception of certain compressive episodes during Late Triassic-Early Liassic, the sector between Rabat and Khenifra has not suffered from any important tectonic activity and that the pre-Variscan structures have not played an important role in the tectonic evolution of the area.

The ATF ages obtained for the granites of the Rabat-Khenifra sector vary between the range 210 and $239 \mathrm{Ma}$ (Figs. 2 and 6). Sample IM-16 in the Middelt area has been taken from Barbero et al. (2007) for comparison. Mean track length (horizontal TINTS) vary in the range of 11.92 to $13.01 \mu \mathrm{m}$. $D_{\text {par }}$ values (diameter of the etch pits in

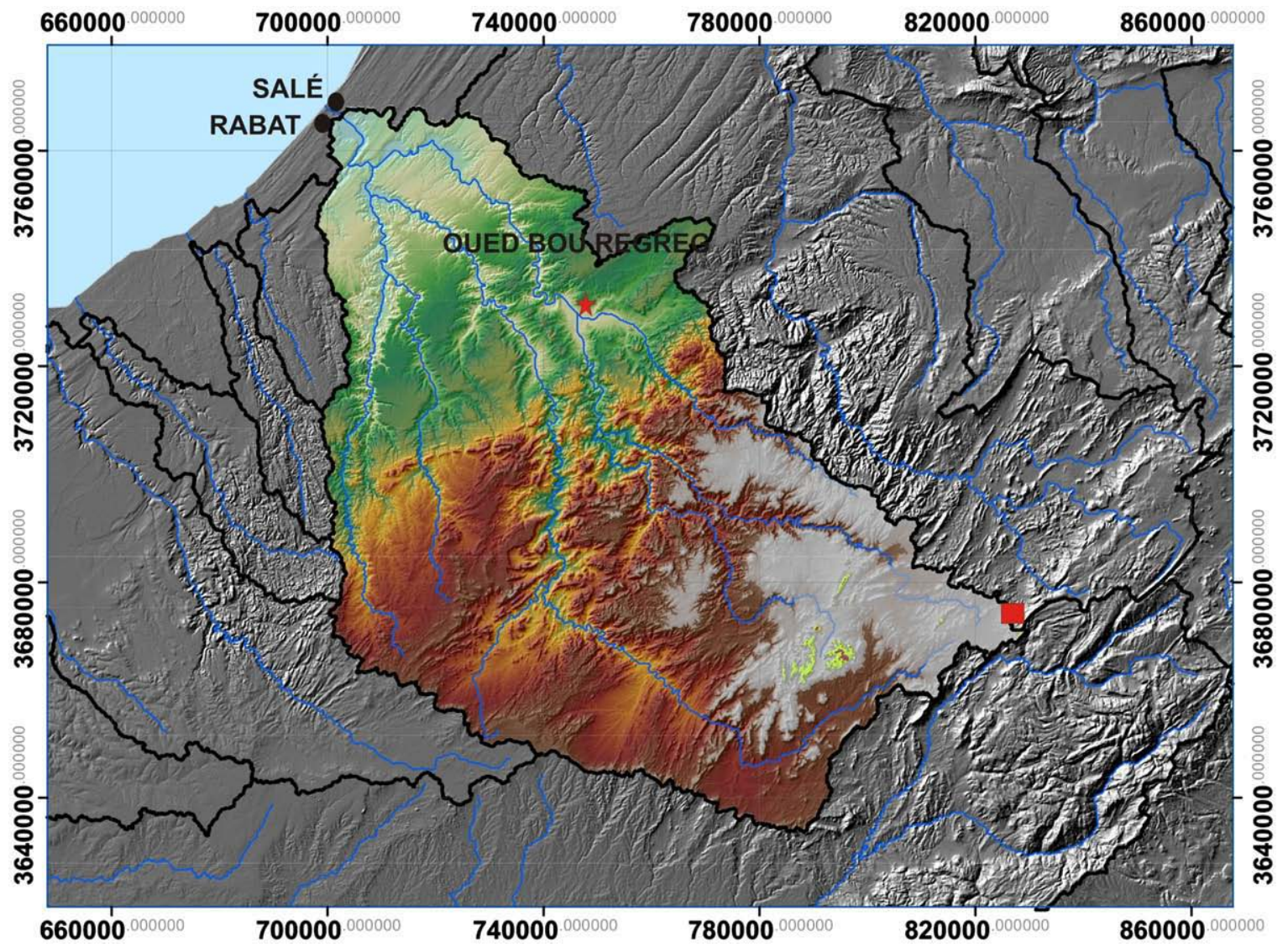

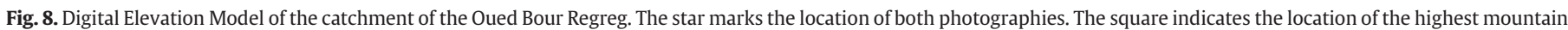
within the watershed divide $(1551 \mathrm{~m})$, while the red zones correspond to the areas within the catchment that have greater attitude than this mountain. 
Table 1

Fission track data of samples from the western Moroccan Meseta.

\begin{tabular}{|c|c|c|c|c|c|c|c|c|c|c|}
\hline $\begin{array}{l}\text { Sample } \\
\text { no. }\end{array}$ & $\begin{array}{l}\text { Elevation } \\
\text { (masl) }\end{array}$ & $\begin{array}{l}\text { No. of } \\
\text { grains }\end{array}$ & $\begin{array}{l}\text { CN-5 track density } \\
\left(\times 10^{6} \mathrm{tr} / \mathrm{cm}^{2}\right) \\
\text { (no. of tracks) }\end{array}$ & $\begin{array}{l}\text { Spontaneous track } \\
\text { density }\left(\times 10^{6} \mathrm{tr} / \mathrm{cm}^{2}\right) \\
\text { (no. of tracks) }\end{array}$ & $\begin{array}{l}\text { Induced track density } \\
\left(\times 10^{6} \mathrm{tr} / \mathrm{cm}^{2}\right) \\
\text { (no. of tracks) }\end{array}$ & $\begin{array}{l}\chi^{2} \\
\text { probability \% }\end{array}$ & $\begin{array}{l}\text { Fission track } \\
\text { central age } \\
( \pm 1 \sigma)(\mathrm{Ma})\end{array}$ & $\begin{array}{l}\text { Mean track } \\
\text { length }(\mu \mathrm{m}) \\
\text { (no. of tracks) }\end{array}$ & $\begin{array}{l}\text { Std dev. } \\
(\mu \mathrm{m})\end{array}$ & $\begin{array}{l}\text { Dpar } \\
(\mu \mathrm{m})(\mathrm{no} .)\end{array}$ \\
\hline RO-1 & 614 & 20 & $1.262(5851)$ & $3.081(2960)$ & $3.006(2888)$ & 27.34 & $215 \pm 7$ & $11.92(112)$ & 2.27 & $3.75(231)$ \\
\hline RO-2 & 659 & 13 & 1.249 (5789) & $4.244(2980)$ & $4.150(2914)$ & 18.19 & $213 \pm 8$ & $12.42(110)$ & 1.74 & $2.31(200)$ \\
\hline $\mathrm{RO}-3$ & 598 & 20 & $1.242(5758)$ & $4.575(3255)$ & $4.461(3174)$ & 7.21 & $212 \pm 11$ & $12.41(115)$ & 1.72 & $1.87(250)$ \\
\hline RO-7 & 1129 & 20 & 1.275 (5912) & $1.848(3612)$ & 1.959 (3828) & 24.04 & $202 \pm 7$ & $13.01(77)$ & 2.15 & $3.05(230)$ \\
\hline RO-8 & 990 & 10 & $1.256(5820)$ & $0.864(428)$ & $0.816(404)$ & 9.89 & $222 \pm 20$ & & & \\
\hline $\mathrm{TA}$ & 200 & 19 & 1.339 (6209) & 2.885 (1969) & 2.919 (1992) & 82.62 & $220 \pm 8$ & $12.11(75)$ & 1.70 & $2.18(205)$ \\
\hline BJE & 95 & 14 & 1.309 (6069) & $1.423(578)$ & $1.317(535)$ & 27.29 & $239 \pm 18$ & $12.20(12)$ & 2.10 & $1.85(40)$ \\
\hline
\end{tabular}

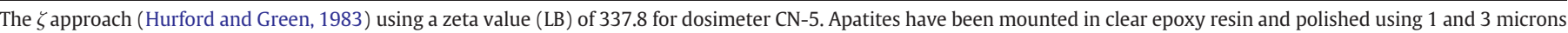

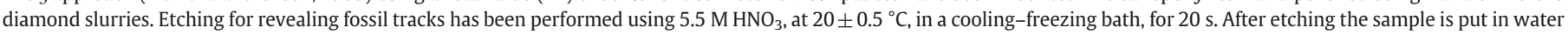

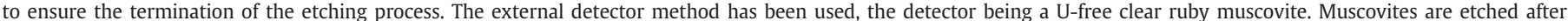

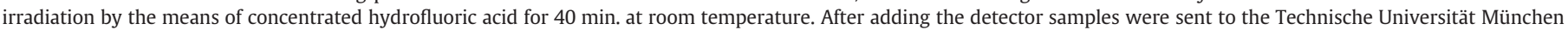

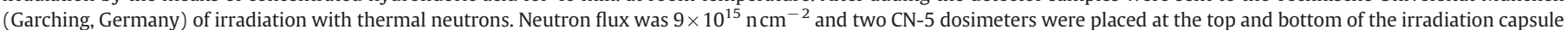

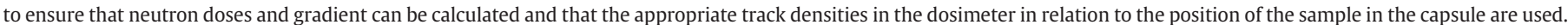

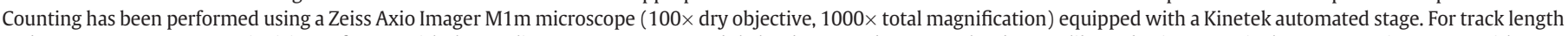

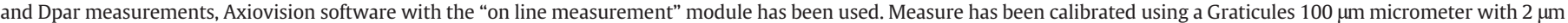
divisions.

spontaneous tracks measured parallel to the c-axis) are all very similar and average vary between 1.85 and $3.75 \mu \mathrm{m}$ which points to compositions similar to the Durango apatite.

An inverse correlation $\left(R^{2}=0.84\right)$ between AFT age and sample elevation (AER) is observed (Fig. 9) for all samples. This is a remarkably interesting feature, as in exhumed basement areas the relation between elevation and AFT ages is normal, the highest samples showing older AFT ages than the lowest ones. As it will be discussed later, the inverse AER is generally attributed to rapid relief changes (see discussion in Braun, 2002).

Thermal modelling has been performed generating random $t-T$ paths using a Monte Carlo algorithm (Ketcham, 2005). Input parameters are fission-track ages and errors of individual crystals, track length distribution histogram, $D_{\text {par }}$ values as kinetic indicator. External constraints used are similar to those used by Ghorbal et al. (2008) and include the following: a box to allow high temperatures following emplacement age (320-370 Ma, Mrini et al., 1992); another box to allow the rocks to be at surface or close to surface at Permian to
Triassic times as there are geological evidences of Triassic sediments overlaying the crystalline massif; a third box to explain the presence of Cenomanian marine deposits over the Meseta (Harmand and Laville, 1983). Annealing model used is Ketcham et al. (2007). C-axis track length projection (Ketcham et al., 1999) has been used.

Obtained thermal models show stages of cooling and heating broadly similar to those found by Ghorbal et al. (2008), in relation to far-field effects of the Atlantic rifting and post-rifting stages and to large scale folding coeval with shortening related to the Atlas and Rif orogens (Fig. 10).

\section{Discussion}

\subsection{Post-Variscan evolution}

In certain samples such as RO- 1 and TA, thermal evolution is characterized by a heating period at around $150 \mathrm{Ma}$ reaching maximum temperatures of ca. $110^{\circ} \mathrm{C}$. This is not evident in models

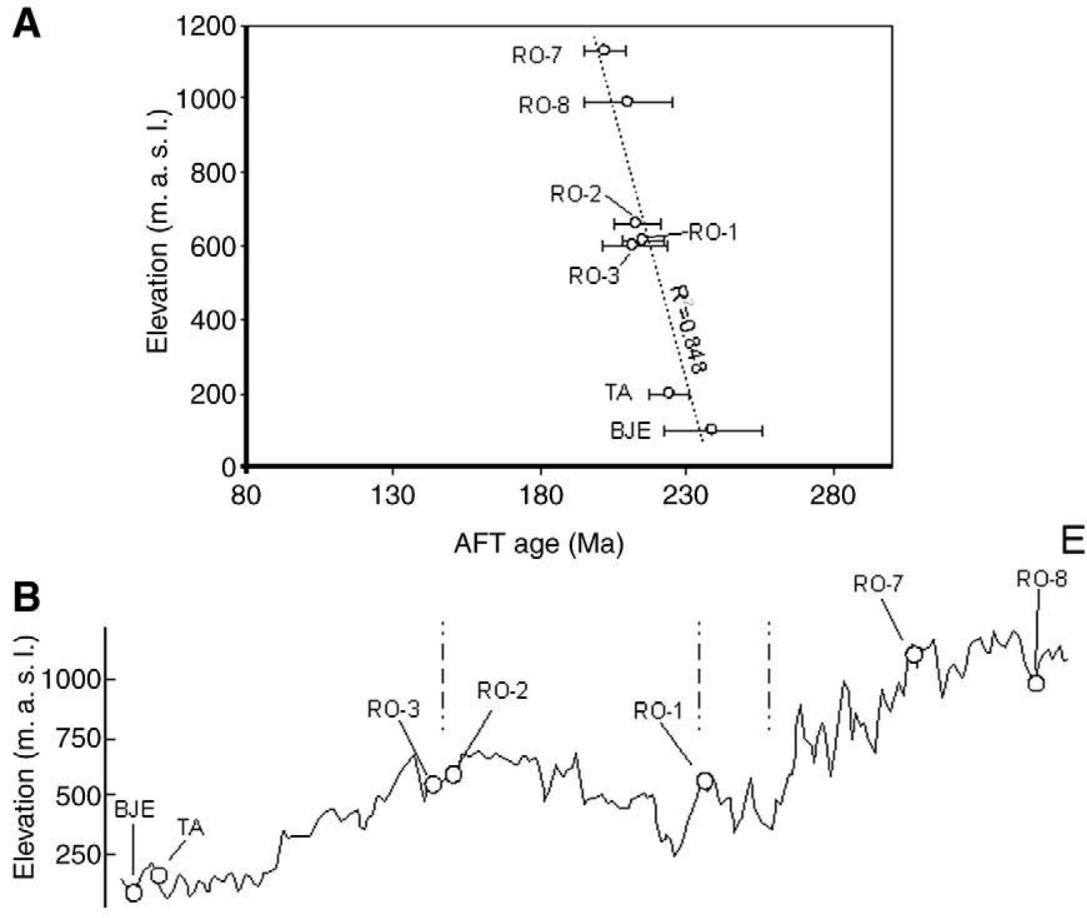

Fig. 9. Age vs. elevation plot showing and inverse relationship. Topographic profile (marked as a white line in Fig. 4) shows the location of samples. 

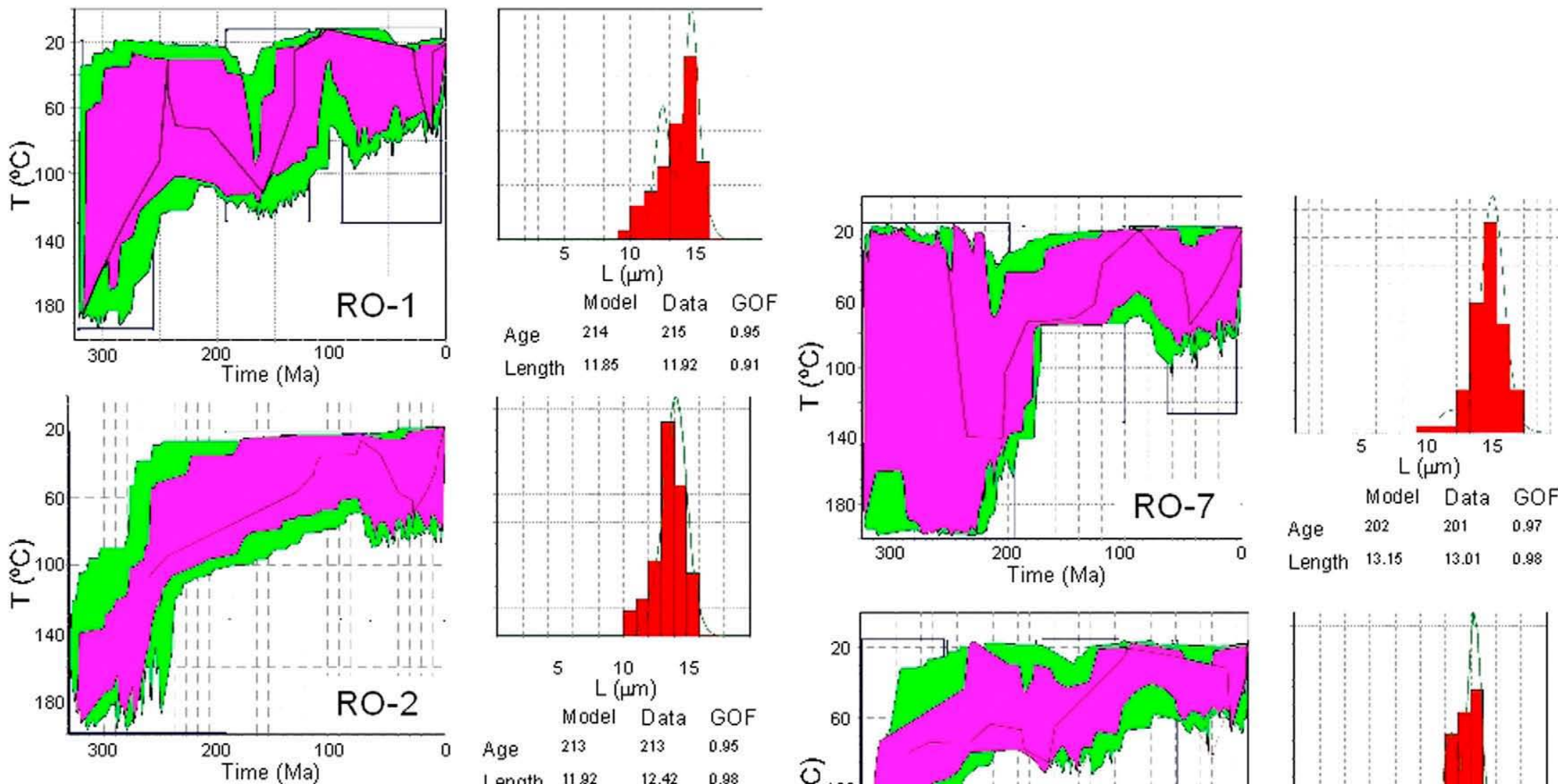

$5 \quad 10,15$ $\mathrm{L}(\mu \mathrm{m})$

Model Data GOF $\begin{array}{llll}\text { Age } & 213 & 213 & 0.95 \\ \text { Length } & 11.22 & 12.42 & 0.98\end{array}$
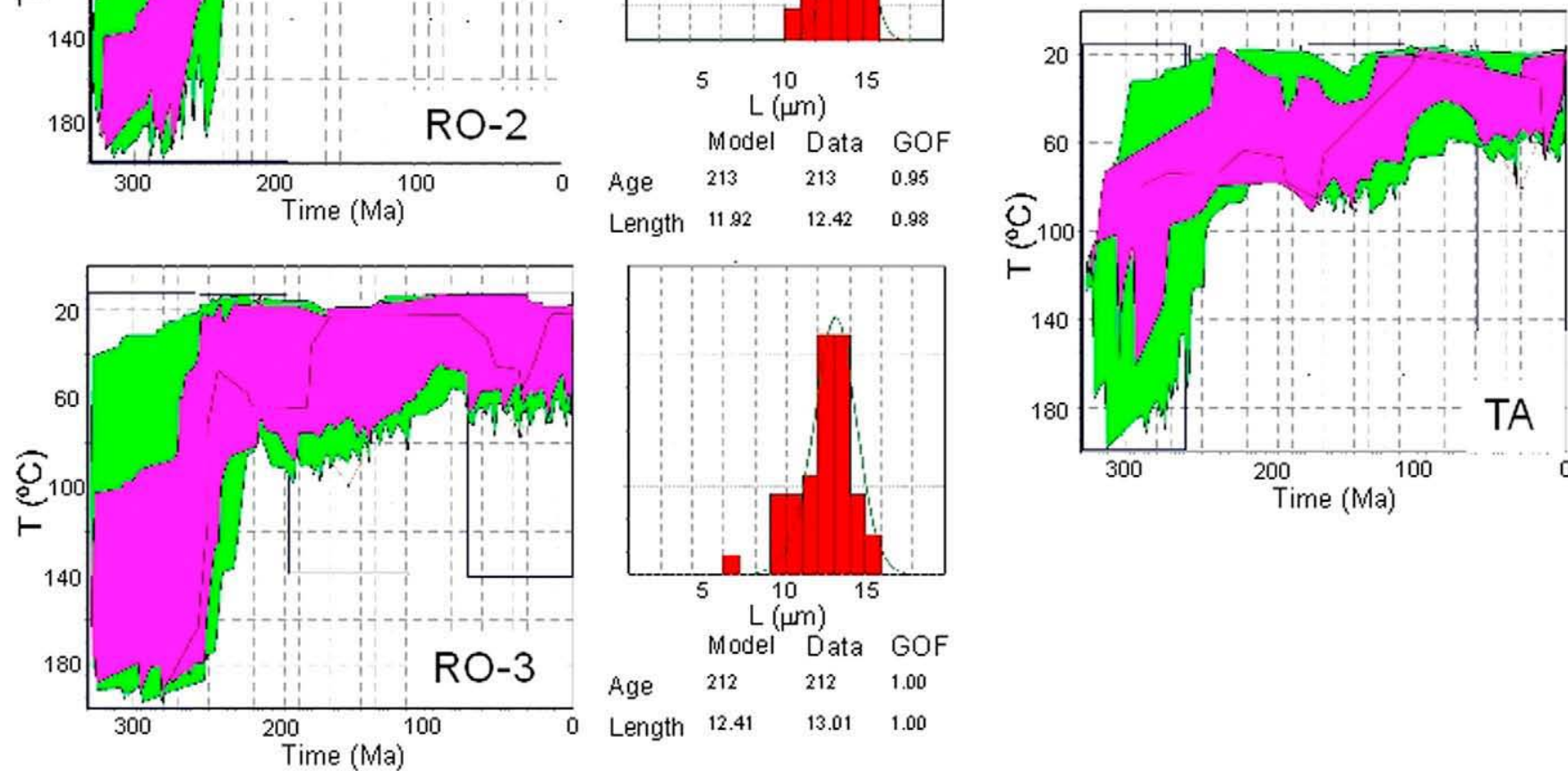

$\begin{array}{llll}\text { Age } \quad 202 & 201 & 0.97\end{array}$

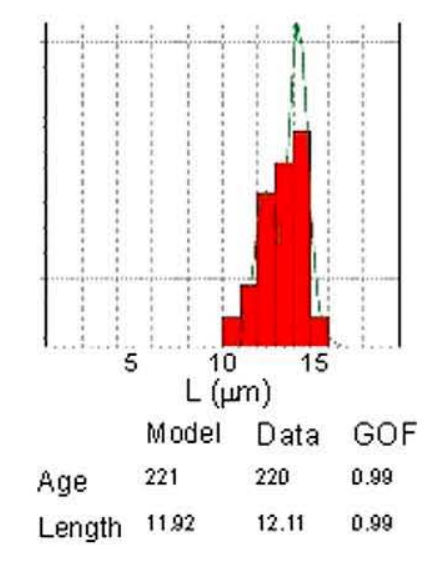


made in samples RO-2 and RO-3 but nevertheless the thermal history modelled is not incompatible with such a heating period. This Jurassic-Early Cretaceous heating period has been also recognized in the same area by Ghorbal et al. (2008) and could be related to a combination of subsidence coeval with the beginning of the Atlantic rifting and the relaxation of the Late-Variscan thermal anomalies. Ghorbal et al. (2008) emphasized that this Jurassic-Early Cretaceous subsidence affected an area stretching from the Atlantic margin to the Atlas.

Following this first heating episode, a post-rift stage is characterized by a cooling rate of ca. $2{ }^{\circ} \mathrm{C} / \mathrm{Ma}$ and exhumation can be claimed also on the bases of the presence of terrigenous sediments deposited on the Atlantic margin (Price, 1981; Davison, 2005). From the Late Cretaceous to present a second period of heating at rates not well defined by models affected the studied area. Results of Ghorbal et al. (2008) also show that this is the case for other parts of the Variscan basement located to the south of the Meseta (Rehamma massif). These authors relate this heating to large scale subsidence affecting the whole area between the Atlas and Rif belts as a consequence of large scale folding in relation to shortening which originated the Atlas and Rif belts.

Nevertheless AFT ages in the present work are at least c. $50 \mathrm{Ma}$ older than the age given for the Romani pluton of these authors which is $147.9 \pm 6 \mathrm{Ma}$.

Modelling results in all samples evidence that the whole block of the WM has cooled as a single block and there is no differential cooling or heating related to fault creation or reactivation of previous faults.

\subsection{Thermochronometric evidences for recent surface uplift}

Several papers have recently proposed that low temperature thermochronological data can be used to provide insights on past topography and its evolution though time (Braun, 2002; Reiners, 2007). The rationale under this statement is that at a certain location characterized by different dominant wavelengths, for a given thermochronometer with a closure temperature $T_{\mathrm{c}}$, at short horizontal distances, there is a positive correlation between elevation and cooling ages as the closure temperature isotherm at these short scales can be considered horizontal for all samples. At larger horizontal distances, samples taken at different locations over a large scale, will show similar cooling ages and no positive age-elevation relationship because the closure isotherm follows the long-wavelength topography (see Figures 1 and 2 in Reiners (2007)). Braun (2002) defines a critical topographic wavelength parameter for representing the sensitivity of a given thermochronometer to a topography characterized by a given wavelength, as the ratio of the closure temperature to the geothermal gradient. Considering a closure temperature for the apatite fission-track system of around $110{ }^{\circ} \mathrm{C}$ and a present-day value for the geothermal gradient of $25^{\circ} \mathrm{C} / \mathrm{km}$, the critical topographic wavelength is $4.4 \mathrm{~km}$. So, samples taken at a larger scale than this value will provide information on changes due to erosion and topography. As previously mentioned samples from the RabatKhenifra section were taken at a scale larger than this $4.4 \mathrm{~km}$ and show an inverse AER which can be taken as an indication of the effect of recent changes in topography (Braun, 2002).

The analysis of the present-day topography performed in this work show that 60 and $100 \mathrm{~km}$ wavelength components are present in the WM. With these wavelengths of topography it is possible to estimate the admittance ratio (the ratio of the relief of the closure isotherm $\left(\sim 110^{\circ} \mathrm{C}\right)$ to the relief of topography, Reiners, 2007). In our case the admittance ratio varies between 0.60 and 0.65 i.e. the apatite closure isotherm is bent by about $60-65 \%$ and this highlights the importance of the wavelength topography over the topographic amplitude which has a minor effect. So, for the WM it is clear that the variation in AFT ages reflect not only the effects of erosion but also the effects of present-day changes in topography.

On a big scale the inverse AER is commonly attributed to isostatic rebound (Braun et al., 2006) but this is not the only explanation. In the context of the Atlas Mountains, Babault et al. (2008) have shown that at lithospheric scale, the average elevation of the whole Atlas and adjacent plateaux describe a lithospheric dome onto which the recent Atlas topography is superimposed. They offer abundant geologic evidence for this (tilted Pliocene lacustrine sediments, uplifted Upper Miocene marine deposits and drainage reorganization). The large scale surface deformation coincides with the N-E trending imaged thinning of the lithosphere in this region, which is the attributed to a buoyant mantle upwelling (Teixell et al., 2008; Babault et al., 2008). This is consistent with several geological evidences including the occurrence of alkaline magmatism of Cenozoic age in the region and the significant contribution of mantle-derived gas in the thermal waters of the Oulmès area (Tassi et al., 2006).

The AFT data of the Paleozoic coastal basement indicate that a recent process, occurred at temperatures lower than the upper part of the apatite partial annealing zone $\left(<60{ }^{\circ} \mathrm{C}\right)$, has changed the topographic elevation of the samples, the AFT ages resulting unchanged. Whether this is related to flexural subsidence and isostatic rebound related to erosional unloading and lithospheric folding or is associated to a mantle plume or a combination of both mechanisms can not be resolved with the actual FT data. Both lithospheric folding and mantle plume activity mechanisms result in very similar topographic expression (Burov and Cloetingh, 2009 and references there in) and present AFT and geomorphic data point to an interrelation of both, the relevance of each being very difficult to assess with the available data. In any case, these data and the results of the study of different geomorphic indicators support a recent northwards tilting of the Paleozoic coastal basement in agreement with other geological evidences as those of Babault et al. (2008).

Corrected (U-Th)/He age on the Romani pluton (Ghorbal et al., 2008) varies between 242 and 50.6 Ma. Although this is a wide range they are consistent with the proposed thermal models as this indicates a likely deceleration of the cooling rate after exiting the apatite partial annealing zone.

\subsection{Evidences from geomorphic indicators}

Results from modelling are also consistent with a recent tilting as shown in Fig. 3 although the precise timing for this can not be precisely resolved, but is more recent than 20-25 Ma (see Fig. 3) in accordance with an estimated age of $15 \mathrm{Ma}$ for the main episode of long-wavelength mantle-related uplift in the Atlas Mountains (Teixell et al., 2005; Missenard et al., 2006).

The trend-topography surface analysis allows us to identify some NE-SW trending undulations in the relief of the Atlas Mountains and the WM. A large-scale undulation is the main feature in the harmonic surface obtained through a Fourier analysis with a wavelength of $200 \mathrm{~km}$. This undulation corresponds to the high topography of the Atlas Mountains. The horizontal shortening of these mountains is not enough to explain their high topographic elevations, which are probably related to a lithospheric doming process studied by Teixell et al. (2005, 2008), Missenard et al. (2006), and Babault et al. (2008). The presence of a regional northwards tilting of the whole WM younger than 20 to $25 \mathrm{Ma}$ obtained through the fission tracks agrees with this doming process, as the Meseta is located in its northwest flank. Therefore, the lithospheric doming process is not only the responsible of the high elevation of the Atlas Mountains, but also of a regional northwest tilting of the $\mathrm{WM}$.

The harmonic surfaces 100 and $60 \mathrm{~km}$ wavelength also show a medium-scale NE-SW undulations are found within the WM. These undulations superimpose to the large-scale main undulation and they 
are related with folding and thrusting under a N-S to NW-SE compression context.

The hypsometric analysis also reveals that medium-scale folds cause anomalies in the drainage network of the WM. The presence of convex inflections in the large basins draining the core of the WM indicates younger relief in the central and upper parts of these basins. They are the consequence of a modification of a drainage network running to the NE generated by the doming process. These folds also could be the responsible of the drainage of the Oued Oum Er Rbia river in its head part. This river flows in their head and middle reaches with a NE-SW direction, thus being orthogonal to the main northwest tilt of the WM. Since modifications in the drainage network are thought to be related with relatively recent events (as rivers are always attaining a dynamic equilibrium) we can propose that these foldrelated anomalies are younger than 20 to $25 \mathrm{Ma}$ regional tilting produced by doming.

However, the $\xi$-shaped curves are clearly anomalous, especially due that the higher parts of the catchment are in the centre of the basin and not in the watershed divide (Oued Bou Regreg, Fig. 8). We propose that these facts were produced by the modification of a previous mature drainage network similar to that of the Oued Oum Er Rbia by the doming of the WM (domes with a wavelength of 60$100 \mathrm{~km}$ ). The formation and rising of the central dome to elevations around $1600 \mathrm{~m}$ in the middle part of the drainage basins, induced the vertical incision of the rivers in this area, while they were not modified in the mouth and in the watershed divide areas, where the lateral incision was taking place.

\section{Conclusions}

The present paper presents the results of a combined apatite fission-track thermochronology and geomorphic study of the Western Variscan Meseta of Morocco. Results from fission-track ages and data modelling show that:

(1) A long post-Variscan thermal history is preserved in the apatite fission-track thermal signal, showing several periods of cooling and heating that can be related to Jurassic to Early Creataceous rifting which seems to be widespread along the southernmost Variscan chain and also to the subsidence in relation to shortening which originated the Atlas and Rif belts.

(2) An inverse age-elevation relationship is found in the sample which is a remarkable feature consistent with a recent change in topography. Thermal models are also compatible with a recent cooling in relation to surface uplift.

(3) Different geomorphologic indicators support the apatite fission-track results. A detailed analysis of the topography at different scales in the western Moroccan Meseta indicate that two open folds with different amplitudes are recognized and that the one with wider wavelength could correspond to a lithospheric dome as previously stated by other authors on the basis of independent geological arguments. Also, the presence of convex inflections in the large basins draining the core of the WM indicates younger relief in the central and upper parts of these basins which is compatible with a recent doming process. The open fold with 80 to $60 \mathrm{~km}$ wavelength could represent the response of the crust to the Atlas shortening with a deformational front that is migrating towards the WM.

\section{Acknowledgements}

This work is supported by CONSOLIDER INGENIO 2010 project CSN2006-00041 and Junta de Andalucía PAI groups RNM-160 and RNM-148. This work was co-financed by the AECI cooperation projects $A / 3458 / 05, A / 5904 / 06$, and A/010149/07, and also by the research project PO-RNM-347 from the Junta de Andalucía. Fernando
Simancas is thanked for providing samples TA and BJE in the Rabat area. Jurgen Foeken, Sierd Cloetingh and an anonymous reviewer are thanked for the detailed revision the manuscript.

\section{References}

Ait Brahim, L., Chotin, P., Hinaj, S., Abdelouafi, A., El Adraoui, A., Nakcha, C., Dhont, D. Charroud, M., Sossey Alaoui, F., Amrhar, M., Bouaza, A., Tabyaoui, H., Chaouni, A. 2002. Paleostress evolution in the Moroccan African margin from Triassic to Present. Tectonophysics 357, 187-205.

Ayarza, P., Alvarez-Lobato, F., Teixell, A., Arboleya, M.L., Teson, E., Julivert, M., Charroud M., 2005. Crustal structure under the central High Atlas Mountains (Morocco) from geological and gravity data. Tectonophysics 400, 67-84.

Babault, J., Teixell, A., Arboleya, M.L., Charroud, M., 2008. A late Cenozoic age for longwavelength surface uplift of the Atlas Mountains of Morocco. Terra Nova 20 $102-107$.

Barbero, L., Teixell, A., Arboleya, M.L., del Río, P., Reiners, P.W., Bougadir, B., 2007. Jurassic-to-present thermal history of the central High Atlas (Morocco) assessed by low-temperature thermochronology. Terra Nova 19, 58-64.

Bargach, K., Ruano, P., Chabli, A., Galindo-Zaldívar, J., Chalouan, A., Jabaloy, A., Akil, M., Ahmamou, M., Sanz de Galdeano, C., Benmakhlouf, M., 2004. Recent tectonic deformations and stresses in the frontal part of the Rif Cordillera and the Saiss Basin (Fes and Rabat regions, Morocco). Pure Appl. Geophys. 161 (3), 521-540.

Baudin, T., Chèvromont, P., Razin, P., Thiéblemont, D., Rachid, C.H., Roger, G., Benhaourch, R., Winkel, A., 2001. Carte géologique du Maroc au 1/50000, feuille d'Oulmés, Mémoire explicative. Notes et Mémoires du Sevice Géologique du Maroc № 410 bis. (in French).

Braun, J., 2002. Quantifying the effect of recent relief changes on age-elevation relationships. Earth Planet. Sci. Let. 200, 331-343.

Braun, J., van der Beek, P., Batt, G., 2006. Quantitative Thermochronology. Cambridge University Press, New York. 258 pp.

British Oceanographic Data Centre, 2003. GEBCO One Minute Grid. GEBCO Digital Atlas CD-rom.

Burov, E., Cloetingh, S., 2009. Control of mantle plumes and lithopheric folding on modes of intraplate continental tectonics: differences and similiarities. Geophys. J. Int. 178, 1691-1722.

Chèvromont, P., Cailleux, Y., Baudin, T., Razin, P., Thiéblemont, D., Hoepffner, C., Bensahal, A., Benhaourch, R., 2001. Carte géologique du Maroc au 1/50000, feuille d'Ezzhiliga, Mémoire explicative. Notes et Mémoires du Sevice Géologique du Maroc № 413 bis. (in French).

Davison, I., 2005. Central Atlantic margin basins of the North West Africa: geology and hydrocarbon potential (Morocco to Guinea). J. Afr. Earth Sci. 43, 254-274.

El Hadi, H., Simancas, J.F., Tahiri, A., González-Lodeiro, F., Azor, A., Martínez-Poyatos, D. 2006. Comparative review of the Variscan granitoids of Morocco and Iberia: proposal of a broad zonation. Geodin. Acta 19 (2), 103-116.

Fullea, J., Fernández, M., Zeyen, H., Vergés, J., 2007. A rapid method to map the crusta and lithospheric thickness using elevation, geoid anomaly and thermal analysis. Application to the Gibraltar Arc System, Atlas Mountains and adjacent zones. Tectonophysics 430, 97-117.

Fullea-Urchulutegui, J., Fernández, M., Zeyen, H., 2006. Lithospheric structure in the Atlantic-Mediterranean transition zone (southern Spain, northern Morocco): a simple approach from regional elevation and geoid data. In: de Lamotte, D. Frizon, Saddiqi, O., Michard, A. (Eds.), Some recent Developments on the Maghreb Geodynamics: C. R. Geoscience, vol. 338, pp. 140-151.

Ghorbal, B., Bertotti, G., Foeken, J., Andriessen, P., 2008. Unexpected Jurassic to Neogene vertical movements in "stable" parts of NW Africa revealed by low temperature geochronology. Terra Nova 20, 355-363.

Guiraud, R., Bosworth, W., Thierry, J., Delplanque, A., 2005. Phanerozoic geological evolution of Northern and Central Africa: an overview. J. Afr. Earth Sci. 43, 83-143.

Harmand, C., Laville, E., 1983. Magmatisme alcalin mésozoïque et phénomènes thermiques associés dans le Haut Atlas central (Maroc). Bull. Cent. Rech. Explor. Prod. Elf-Aquitaine 7, 367-376 (in French)

Hoepffner, C., Soulaimani, A., Alain Piqué, A., 2005. The Moroccan Hercynides. J. Afr. Earth Sci. 43, 144-165. doi:10.1016/j.jafrearsci.2005.09.002.

Hurford, A.J., Green, P.F., 1983. The zeta calibration of fission track dating. Chem. Geol. 1, 285-317.

Hurtrez, J.E., Sol, C., Lucazeau, F., 1999. Effect of drainage area on hypsometry from an analysis of small-scale drainage basins in the Siwalik Hills (central Nepal). Earth Surf. Proc. Land. 24, 799-808.

Johansson, M., 1999. Analysis of digital elevation data for paleosurfaces in southwestern Sweden. Geomorphology 26, 279-295.

Ketcham, R.A., 2005. Forward and inverse modelling of low-temperature thermochronology data. Rev. Mineral. Geochem 58, 275-314.

Ketcham, R.A., Donelick, R.A., Carlson, W.D., 1999. Variability of apatite fission track annealing kinetics II: extrapolation to geological time scales. Am. Mineral. 84 1235-1255.

Laville, E., 1985. Evolution sédimentaire, tectonique et magmatique du bassin Jurassique du Haut Atlas, Maroc: modèle en relais multiples de décrochements. $\mathrm{Ph}$. Doctoral Thesis, Univ. Montpellier, France.

Lifton, N.A., Chase, C.G., 1992. Tectonic, climatic and lithologic influences on landscape fractal dimension and hypsometry: implications for landscape evolution in the San Gabriel Mountains, California. Geomorphology 5, 77-114. doi:10.1016/0169-555X (92)90059-W. 
Mahmood, A., Bennani, A., 1983. S-type characteristics of the Hercynian granitoids of the Central Palaeozoic Massif, Morocco. Geol. Mag. 121 (4), 301-309.

Masek, J.G., Isacks, B.L., Gubbels, T.L., Fielding, E.J., 1994. Erosion and tectonics at the margins of continental plateaus. J. Geophys. Res. 99 (13), 941-13,956. doi:10.1029/ 94JB00461.

Michard, A., 1976. Eléments de géologie marocaine. Notes Mém. Serv. Geol. Maroc. 252, $408 \mathrm{p}$.

Michard, A., Cailleux, Y., Hoepffner, C., 1989. L'orogénese mésétien du Maroc: structure, deformation hercynienne et déplacements. Mem. Serv. Geol. Maroc. 335, 313-327.

Michard, A., Hoepffner, C., Soulaimani, A., Baidder, L., 2008. Chapter 3. The Variscan belt Continental Evolution: The Geology of Morocco. : Lecture Notes in Earth Sciences, vol. 116. Springer-Verlag, Berlin, Heidelberg, pp. 65-132.

Missenard, Y., Zeyen, H., Frizon de Lamotte, D., Leturmy, P., Petit, C., Sébrier, M., Saddiqi, O., 2006. Crustal versus asthenospheric origin of relief of the Atlas Mountains of Morocco. J. Geophys. Res. 111, B03401. doi:10.1029/2005JB003708.

Mrini, Z., Rafi, A., Duthou, J.L., Vidal, P., 1992. Chronologie Rb-Sr des granitoïdes hercyniens du Maroc: conséquences. Bull. Soc. Geól. Fr. 163, 281-291 (in French)

O'Callaghan, J.F., Mark, D.M., 1984. The extraction of drainage networks from digital elevation data. Comp. Vis. Graph. Image Process. 28, 323-344.

Ohmori, H., 1993. Changes in the hypsometric curve through mountain building resulting from concurrent tectonics and denudation. Geomorphology 8, 263-277.

Pérez-Peña, J.V., Azañón, J.M., Azor, A., 2009a. CalHypso: an ArcGIS extension to calculate hypsometric curves and their statistical moments. Applications to drainage basin analysis in SE Spain. Comput. Geosci 35, 1214-1223. doi:10.1016/j.cageo.2008.06.006.

Pérez-Peña, J.V., Azañón, J.M., Azor, A., Delgado, J., González-Lodeiro, F., 2009b. Spatia analysis of stream power using GIS: SLk anomaly maps. Earth Surf. Processes Landf. 34, 16-25. doi:10.1002/esp.1684.

Price, I., 1981. Provenance of the Jurassic-Cretaceous flysch, Deep Sea Drilling Project sites 370 and 416. Initial Rep. Deep Sea Drill. Project 50, 751-757.

Rayner, J.N., 1972. The application of harmonic and spectral analysis to the study of terrain. In: Chorley, R.J. (Ed.), Spatial Analysis Geomorphology. Methuen and Co. Ltd., London, U.K.

Reiners, P.W., 2007. Thermochronologic approaches to paleotopography. Rev. Min. Geochem. 66, 243-267.
Sánchez-Serrano, F. 2000. Análisis de la Topografía y Deformaciones Recientes en el Centro de la Península Ibérica. PhD Thesis, Universidad Complutense de Madrid, Spain, 202 pp.

Schumm, S.A., 1956. Evolution of drainage systems and slopes in badlands at Perth Amboy, New Jersey. Geol. Soc. Amer. Bull. 67, 597-646.

Strahler, A.N., 1952. Hypsometric (area-altitude) analysis of erosional topography. Geol. Soc. Amer. Bull. 63, 1117-1142.

Tahiri, A., Montero, P., El Hadi, H., Martínez Poyatos, D., Azor, A., Bea, F., Simancas, J.F., González Lodeiro, F., 2009. Geochronological data on the Rabat-Tiflet granitoids: their bearing on the tectonics of the Moroccan Variscides. J. Afr. Earth Sci.. doi:10.1016/j.jafrearsci.2009.07.005

Tarboton, D.G., Bras, R.L., Rodriguez-Iturbe, I., 1991. On the extraction of channel networks from digital elevation data. Hydrol. Process. 5, 81-100.

Tassi, F., Vaselli, O., Moratti, G., Piccardi, L., Minissale, A., Poreda, R., Delgado Huertas, A., Bendkik, A., Chenakeb, M., 2006. Fluid geochemistry versus tectonic setting; the case study of Morocco. Geol. Soc. London Spec. Pub. 262, 131-145.

Teixell, A., Arboleya, M.L., Julivert, M., Charroud, M., 2003. Tectonic shortening and topography in the central High Atlas (Morocco). Tectonics 22, 1051. doi:10.1029/ 2002TC001460.

Teixell, A., Ayarza, P., Zeyen, H., Fernandez, M., Arboleya, M.L., 2005. Effects of mantle upwelling in a compressional setting: the Atlas Mountains of Morocco. Terra Nova 17, 456-461.

Teixell, A., Ayarza, P., Tesón, E., Babault, J., Alvarez-Lobato, F., Charroud, M., Julivert, M., Barbero, L., Amrhar, M., Arboleya, M.L., 2008. Geodinámica de las cordilleras del Alto y Medio Atlas: síntesis de los conocimientos actuales. Rev. Soc. Geol. España 20, 333-350 (in Spanish).

Tejero, R., González-Casado, J.M., Gómez-Ortiz, D., Sánchez-Serrano, F., 2006. Insights into the "tectonic topography" of the present-day andscape of the central Iberian Peninsula (Spain). Geomorphology 76, 280-294.

Zeyen, H., Ayarza, P., Fernández, M., Rimi, A., 2005. Lithospheric structure under the western African-European plate boundary: a transect across the Atlas Mountains and the Gulf of Cadiz. Tectonics 24, TC2001. doi:10.1029/ 2004TC001639. 